\title{
State of Research and Trends in the Development of Polyvinyl Acetate-Based Wood Adhesive
}

\author{
Ravindra Vilas Indubai Gadhave* (D), Pritam V. Dhawale \\ Department of Polymer and Surface Engineering, Institute of Chemical Technology, Mumbai, India \\ Email: ^ravi.gadhave3@gmail.com, pritamdhawale28@gmail.com
}

How to cite this paper: Gadhave, R.V.I. and Dhawale, P.V. (2022) State of Research and Trends in the Development of Polyvinyl Acetate-Based Wood Adhesive. Open Journal of Polymer Chemistry, 12, 13-42. https://doi.org/10.4236/ojpchem.2022.121002

Received: January 8, 2022

Accepted: February 7, 2022

Published: February 10, 2022

Copyright ( 2022 by author(s) and Scientific Research Publishing Inc. This work is licensed under the Creative Commons Attribution International License (CC BY 4.0).

http://creativecommons.org/licenses/by/4.0/ (c) (i) Open Access

\begin{abstract}
Synthetic wood adhesives, consisting of urea-formaldehyde resins (UF), phenol-formaldehyde resins (PF), melamine-formaldehyde resins (MF), and polyurethane resins, are widely used. For UF and MF, most investigations are concerned with reducing free formaldehyde content; for PF, most studies focused on finding new alternative chemicals to replace phenol. These adhesives come under the Carcinogenic, Mutagenic, and Reprotoxic chemicals (CMR) category. Due to global energy issues and dependency on petroleum sources, the focus has shifted to look for alternative and renewable raw material sources for wood adhesives. Conventionally available wood adhesives are polyvinyl alcohol (PVA) stabilized, with drawbacks like poor water resistance, poor heat resistance, low-temperature workability, and it's based on petroleum resources. Polyvinyl acetate (PVAc) is non-resistant to moisture polymer, and if such adhesive joints are exploited in a moist environment, its strength substantially decreases. Sufficiently moisture-resistant adhesive joints are obtained by modifying PVAc dispersion with special compounds like reactive comonomer, Silanes, and modified PVA. To improve the workability at low temperature, Vinyl acetate (VAc) is copolymerized with specific comonomers like butyl acetate without affecting the performance properties. Here, we aim to present an overview of the research trend of PVAc-based adhesives in the wood industry. The review summarizes the current state of research PVAc-based adhesives.
\end{abstract}

\section{Keywords}

Polyvinyl Acetate Emulsion, Polyvinyl Alcohol, Bio-Polymers, Wood, Water Resistance, Adhesives 


\section{Introduction}

\section{Wood adhesive}

Wood is a porous material with many inherited anatomical characteristics. Major characteristics are longitudinal tracheids in softwood species and vessel elements and longitudinal fibers in hardwood species. The lumens of their cells are large enough to provide a promising pathway for the flow of liquid resin. Interconnecting pits are often adequate to permit resin flow. However, high-molecular-weight polymeric resins or occlusions in the pits or lumens may inhibit flow. This conglomeration of resin and wood substance is called the "interphase region." Two substrates, each with its interphase, and the interface between them comprise the "bond line." The geometry of the interphase region varies as a result of many factors, such as wood anatomy, permeability, porosity, resin viscosity, surface energy, consolidation pressure, and others [1]. Glue in all industrial sectors is a modern need; it is also essential in the furniture industry. Recently focus has shifted to green adhesives [2].

Wood adhesives account for a considerable part of manufacturing costs. To decrease the manufacturing costs, wood industries use lower-cost economical adhesives, sometimes compromising the quality of the products [3]. Many furniture was made using mechanical connectors, but humans were also looking for wood adhesives from plants and animals [4]-[19]. In the light of increasing public concern about human health and the environment, a decrease of formaldehyde and other carcinogenic, mutagenic, and reprotoxic chemicals (CMR) emissions arising from adhesives is highly desirable. To that end, developing environmentally benign materials that can replace CMR-based wood adhesives is a vital objective [20]. It needed a lot of research on environmental and human-friendly adhesives. Wood glue is a major area of importance for industrial and commercial activities [2].

\section{History of wood adhesive}

The first proof of a substance that was used as an glue dates back to 4000 B.C. Archaeologists have uncovered statues from Babylonian temples with ivory eye balls glued into eye sockets. This tar-like glue has been held for almost 6000 years. Between 1500 - 1000 B.C., the period gave further proof that glue had become a method of assembly. Paintings and murals showed details of wood gluing operations [21] [22]. The first commercial adhesive factory was started in Holland to manufacture animal glue from hides. About 1750, the first glue patent was issued in Britain for fish glue. Patents were then rapidly issued for adhesives using natural rubber, animal bones, fish, starch, and milk protein. By 1900, the United States had several factories producing glue from these bases. The industrial revolution caused an explosion in technical breakthroughs that resulted in new materials becoming available for formulating adhesives. The era of plastics began with the production of Bakelite phenolic, a thermoset plastic, in 1910. Within a year, adhesives using phenolic resin were put on the market. The 1920s, 30s, and 40s saw many new plastics and rubbers synthetically produced, 
many out of an urgent necessity developed during World War II [23]. Environmentally friendly adhesives Glue is the most critical raw material coming after wood in furniture industries. Especially after World War II, glue ameliorated its time and bonding techniques and developments occurring in plywood block board and chipboard production. In the past, plant and animal glues were used. Later they left the place for the synthetic resin. Animal glue has to fight against instability and resistance to hot water and microorganisms, and the lack of block board limits their usage, though the use and application of synthetic resin in plywood production eliminate these drawbacks [24]. From this art, animal and fish glues were refined, and other adhesives were developed, such as an adhesive from egg whites to bond golf leaf. In addition to egg whites, other natural ingredients were used to prepare the glue, such as blood, bones, hide, milk, cheese, vegetables, and grains [25] [26].

\section{Classification of Adhesives Based on Chemistries}

\section{1) Animal glue}

This glue is obtained from skin, bone, and fish residues. Blood is obtained from the raw with blood from slaughterhouses and casein derived from an animal milk protein [27]. They are obtained from waste and by-products of the animal industries. Raw materials of animal adhesives are hides, ligaments, and bones of cattle and other animals. The scraps of the leather industry are also utilized. Adhesives made from hides are of a higher grade than glue obtained from bones and tendons [28].

\section{2) Plant botanical adhesives}

Environmentally friendly adhesives obtained from botanical plants are mostly obtained by processing starchier plants. Plant-derived adhesives are divided into two groups as starch- and cellulose-derived. The first group is adhesives derived from starch extracted from plants, such as corn, rice, potatoes, and wheat, and is generally used in bookbinding, paper bags, and cardboard boxes. The second group of adhesives is made from cellulose, derived from trees, shrubs, or fruits such as bananas, which are used more in stickers affixed to glass.

\section{Protein-based adhesives}

Protein is the oldest kind of adhesive among different raw material sources and primarily includes animal and plant protein [29]. Soybean proteins are the easiest to obtain and account for most of their production of the other plant proteins. The performance of soybean proteins is closely related to the particle size of adhesives, the original condition of surfaces, viscosity and pressure temperature, pressure, and time during processing [30]. Hettiarachchy et al. [31] developed an alkali that changed the performance of soybean protein adhesives to bond lumber and compared it with natural protein adhesives. This change in performance of protein adhesives has the advantages of much better glue strength and water resistance.

Starch-based adhesives 
As an environmentally friendly natural adhesive, Starch adhesives have become of growing interest to scientists. Since starch has outstanding features, such as naturally large molecules, active functional groups, meets environmental requirements, and is low priced, it usually is used as office adhesives. The use of starch as an adhesive in the wood industry is limited, i.e., lousy water resistance, poor storage stability, inadequate liquidity, and molds easily. Therefore, modification to starch is necessary. To improve water resistance and bonding qualities of starch adhesives, the most effective way is to form compact structures of net cross-linking after adhesives have been molded to prevent bulking for the water molecules wedging and causing the destruction of hydrogen bonds. To improve starch adhesives' stability, we can add a stabilizing agent into the adhesives to extend their storage time [32].

\section{Lignin based adhesives}

Lignin is one of the essential natural polyphenols. It is made of phenylpropanoid monomers which become high molecular weight because of their linked $\mathrm{C}-\mathrm{C}$ and ether bonds. The lignin structure is similar to the microscopic structure of phenol-formaldehyde resin. Hence, some references suggest using lignin to replace phenol to make adhesives. Lignin is a compound that has phenyl propane as its skeletal structure and is also an active polymeric compound. Condensation or a cross-linking reaction with urea-formaldehyde can produce lignin-urea formaldehyde adhesives.

\section{Tannic based adhesives}

Tannin is a natural phenolic compound with several active hydroxyl and carboxyl groups, replacing some phenols as raw material for industrial use. As a replacement for phenol or resorcinol, Tannins are produced as a wood adhesive with a neutral glue layer and, compared with UF, solidify rapidly. So far, tannin adhesives have been successfully applied in plywood, particle board, bamboo plywood, and other fields. Problems of tannin glues are primarily those of rapid reactions between tannins and formaldehyde, short adhesive activity, poor water resistance, high viscosity, high dosage, component variation, and easy chemical reactions [33] [34].

\section{3) Synthetic adhesives}

Synthetic adhesives have many advantages, such as extensive application, easy-to-use, high economic efficiency, and rapid development. All synthetic adhesives are not toxic in nature. Some of synthetic adhesives like UF and PF, they are formaldehyde realising adhesive. To reduce the toxicity of such adhesives, we can blend natural biopolymers like starch with them. In the wood industry, urea-formaldehyde resins (UF), phenol-formaldehyde resins (PF), polyvinyl acetate (PVAc) emulsion, and isocyanate adhesives have extensive ranges of application with promising market prospects. In the 1930s, synthetic resin adhesives were used in the woodworking industry. They have many advantages for use in the woodworking industry and some of disadvantages like based on petroleum sources, toxicity and costly. In outdoor furniture, synthetic resin adhesives can be used in joints that remain as strong as the wood even in unprotected 
exposure to the weather. Inorganic adhesives are based on typical compounds, such as sodium silicate, magnesium oxychloride, lead oxide, sulfur, and various metallic phosphates [35].

\section{Polyvinyl acetate adhesives}

Polyvinyl resin emulsions are also called white glues, are thermoplastics, softening when the temperature is increased to a particular level and hardening again when cooled. PVAc adhesives are copolymer-based. PVAc adhesive solidifies by evaporation or absorption of water by the gluing material [36]. PVAc is used for general assembly applications, film overlay and high-pressure lamination, edge gluing, wood veneer, and edge bonding as a furniture adhesive.

\section{Hot-melt adhesives}

To spread and for adhesion of substrates, adhesives should have the "soaking" feature. In most adhesives used in packaging, an easily evaporating agent such as water flow is used to dissolve the adhesive. It evaporates, leaving behind a sticky substance, and it easily glues. On the other hand, a solvent is used in Hot-melt before applying instead of dissolving it. The solidification of hot melt adhesives can cause the unifying feature. Heat dissipates more quickly in the case of a volatile liquid, even for a waterproof layer. Fast heat dissipation provides quick bond formation. Hot-melt adhesives are furnished in the solid form [37] [38] [39].

\section{Contact adhesives}

Contact adhesives are generally based on synthetic rubber, obtained by dissolving in suitable liquids. As a result of evaporation of the flux contained in the glue, the glue dries. Bonding of large surfaces with contact adhesive is difficult Contact adhesives are usually used to bond:

- Plastic laminates to plywood or particleboard for counter-tops,

- Restaurant and kitchen tables,

- Edge of particle boards and medium-density fiberboard (MDF),

- Upholstering of sofas, and

- Polyvinyl chloride (PVC) edge to panels [40].

\section{Urea-formaldehyde resin adhesives}

Urea-formaldehyde resins are widely used in chipboard or plywood production. UF resin is produced by heating suitable urea and formaldehyde at $115^{\circ} \mathrm{C}$ for 5 hours. They are usually produced during the production of high-quality glue E3 formaldehyde emissions. UF resins came into the market in the 1930s. UF resin can be formulated for hot pressing or room temperature curing by different types and amounts of catalyst. They are also marketed as dry powders, with or without incorporating the catalyst [41].

\section{Melamine resin adhesives}

Melamine-formaldehyde resin (MF) is obtained from polycondensation of melamine and formaldehyde. In the reaction between formaldehyde and melamine, the melamine gives derivatives containing different numbers of methyl groups participating amine group. The number of methyl groups may be up to six. Applications and Properties MF resins are usually used in the impregnated decor paper, barrier lining the balance and preservation, post-forming craft, and 
overlays [42].

\section{Phenol-formaldehyde resin}

Phenol-formaldehyde resins (PF), the second-largest wood type of adhesives after UF, have excellent properties to resist weather, water, and temperatures, have high bond strength after their solidification process, and are commonly used in outdoor structures of wood-based panels.

\section{Silicone adhesives}

Silicone adhesives are known as polysiloxanes. In the chemical structure of silicones, silicon $(\mathrm{Si})$ and oxygen $(\mathrm{O})$ atoms are sequentially arranged instead of carbon (C) contained polymer is the common name. Silicone rubbers are also electrically insulating and chemically resistant and maintain flexibility in a wide temperature range. These are the crucial features. It is most commonly used in a protective sheath and insulating varnishes [36] [43].

\section{Polyvinyl Acetate Emulsion}

PVAc is most widely used as an emulsion of PVAc polymers in water. PVAc emulsions are prepared by free radical polymerizing vinyl acetate (VAc) monomers in the presence of polyvinyl alcohol as a protective colloid [44] [45]. Polyvinyl Acetate PVAc is commonly known as "white glue". Polyvinyl acetate (PVAc) emulsion is an odorless and non-flammable adhesive widely used in furniture and other wood product manufacture at room or low temperatures [46] [47]. Polyvinyl acetate (PVAc) adhesive emulsions are commonly used in bonding many porous materials at room temperatures, such as in wood processing, furniture packaging, building decoration, texture bonding, and print bonding [48] [49] [50].

Water-based PVAc dispersions are the most used among the thermoplastic polymers as the basis for glues to be used with wood and wood products [51] Protective colloids like polyvinyl alcohol (PVA) play an important role in the emulsion polymerization of vinyl acetate (VAc) concerning the viscosity and stability of the emulsion and the mechanical properties of the bonds formed in glued wood joints [52] [53]. Emulsion polymerization of vinyl acetate to PVAc needs colloid for stability and enhancing the mechanical properties of the prepared adhesive as shown in Figure 1. DH, molecular weight, and molecular weight distribution of PVA are the main factors determining the colloidal stability.

Water solubility and flexibility increases when the low molecular weight grade of PVA is used as protective colloid. DH affects the water solubility of the colloid. Because of the crystallinity of fully hydrolyzed PVA, it needs to be heated to the boiling point of water for its complete dissolution. In partially hydrolyzed PVA, reduction in crystallinity due to the presence of residual acetate groups makes it soluble in normal water [54] [55]. Modifications are done in PVA with the help of fluorine substituted silanes and Glyoxal Bis (Sodium Hydrogen Sulfite) Adduct to improve the properties [56] [57] [58] [59] [60]. The curing 
<smiles>CC(C)(C)CC(O)CC(O)CC(O)CC(C)(C)O</smiles><smiles>C=COC(C)=O</smiles>

Figure 1. Polyvinyl alcohol stabilized polyvinyl acetate.

process of PVA only includes water evaporation and subsequent formation of hydrogen bondings, which are very much vulnerable to water and elevated temperatures. Of course, there are some cross-linked grades of PVA with improved performance at high temperatures and humid conditions. Research conducted on PVA has focused primarily on improving the water resistance of PVA by several crosslinking mechanisms [61] [62].

\section{Current Issues Using Conventional Polyvinyl Acetate Emulsion Adhesive}

The PVAc-based adhesive is one of the relatively economical adhesives that the wood industry has used for decades. Despite being a non-toxic impact on the environment, PVAc suffers the main drawback. From a physical and chemical standpoint, Wood adhesives are affected by temperature changes and moisture. As regards temperature, this dependence is a common characteristic of thermoplastic polymers. Instead, the water dependence in PVAc wood adhesives is related to these products being applied as water-based dispersions. Therefore surfactants, colloid protectors, and other hydrophilic compounds are present in formulations [63], thus increasing the water affinity of the dispersion compared to the original pure polymer [64] [65]. PVAc has inferior performance in fire and wet conditions. The mechanical performance of PVA adhesive deteriorates with increasing temperature, and it loses its bonding resistance capacity at over $70^{\circ} \mathrm{C}$ [66] [67]. The poor performance of PVA at elevated temperatures stems from the fact that PVA is a thermoplastic polymer, which reaches $\mathrm{Tg}$ at relatively low temperatures. The curing process of PVA only includes water evaporation 
and subsequent formation of hydrogen bondings, which are very much vulnerable to water and elevated temperatures [68].

The wood adhesive should have excellent flexibility, toughness, and fatigue resistance. In addition, the adhesive should be applied in low-cost, high-speed processes and be able to survive storage conditions and repetitive stress [69]. Water-based polyvinyl acetate adhesive (PVAc) has many desirable features and advantages, with only a few limitations [70]-[76],

Advantages:

- Low cost and availability

- No toxicity problems

- No aging problems

- The dried film holds high joint flexibility

- It does not damage the equipment

- Provides invisible, colorless, and transparent glue lines

- Easy and wide for application

Limitations:

- Low resistance to weather and moisture

- Poor resistance to most solvents

- Slow setting speed

- Curing for 1 - 7 days is recommended before handling

Of course, there are some cross-linked grades of PVA with improved performance at elevated temperatures and humid conditions. Research conducted on PVA has focused primarily on improving the water-resistance of PVA by several approaches [77]-[85], and little attempt was made on the area of heat resistance.

\section{Research Trend in the Development of Wood Adhesive Based on Modified Polyvinyl Acetate Emulsions}

\section{1) Filler encapsulated Polyvinyl acetate emulsion}

Some of the study clays are encapsulated in PVAc emulsions. The study relates to the field of PVAc emulsion adhesives, particularly to a Nano clay or montmorillonite (MNT) contained toughened and modified polyvinyl acetate emulsion adhesive and a preparation method for the adhesive. To effectively improve the water-resistance of a polymerization product, through nano clay added in the reaction process, the mechanical property of the adhesive is effectively improved, the toughening and strengthening effect is realized, the polymer viscosity is improved, and the bonding strength is higher [86] [87] [88]. In [89] study investigated the shear strength of heat-treated solid wood of three species (beech, poplar, and fir) bonded with PVAc adhesive reinforced by nano wollastonite (NW). Heat treatment decreased the shear strength of the bonded specimens considerably. This was attributed to several factors, such as a reduction in polar groups in the cell wall, increased stiffness of the cell wall after heat treatment, and a decline in the wettability of treated wood. Nano-clay impacted the bond strength of PVAc with different magnitude depending on the type and 
loading of nano-clay. Shear strength of joints at dry state increased by the addition of nano-clay. The increase was more evident in the nano-clay compatibility with the matrix. Shear strength of joints in the wet state improved as nano-clay loading increased, showing the effectiveness of nano-clay on imparting water resistance in the glue line [90].

PVAc adhesive with fumed silica was prepared, and it has uniform viscosity and good binding strength, moisture resistance, cold resistance, and mechanical stability [91]. PVAc nanocomposites for wood adhesives containing different amounts of colloidal silica nanoparticles (CSNs) were synthesized via in situ one-step emulsion polymerization. The obtained results showed that PVAc nanocomposite's shear strength, including one weight \% CSNs, has the highest shear and tensile strength, about 4.7 and $3.2 \mathrm{MPa}$ [92]. The semi-continuous seeding emulsion polymerization prepared PVAc hybrid emulsions with nanoparticles $\mathrm{SiO}_{2}$. Adhesion strengths of PVAc emulsions modified with nanoparticles $\mathrm{SiO}_{2}$ were improved. Dynamic mechanical analysis (DMA) results indicated that the films of $\mathrm{PVAc} / \mathrm{SiO}_{2}$ hybrid emulsions had the higher storage modulus than the film of PVAc [93] [94].

The nano-titanium dioxide $\left(\mathrm{TiO}_{2}\right)$ was utilized to improve the bonding performance, structure stability, and film-forming properties of renewable starch-based wood adhesive. The results showed that $4 \%$ nano- $\mathrm{TiO}_{2}$ resulted in 6.5 $\mathrm{MPa}$ of shear strength and $6437 \mathrm{~Pa} \cdot s$ of viscosity. In conclusion, the $4 \%$ nano- $\mathrm{TiO}_{2}$ can be employed to prepare starch-based wood adhesives with superior properties for wood application [95].

2) Vinyl acetate grafted on Biopolymer based emulsions

Grafting was an important technique for modifying polymers physical and chemical properties [96].

\section{Starch-based PVAc emulsions}

Graft polymerization of vinyl acetate monomer starch, as shown in Figure 2, and its usage in wood adhesives have gained researchers and industries' interest [97] [98] [99].

Improvements in thermal stability along with bonding strength and water resistance were shown by graft polymerization of vinyl acetate on corn starch [100]-[106].

\section{Cellulose-based PVAc emulsions}

Geng et al. conducted a study in which incorporation of cellulose nanocrystals (CNC) to the crosslinked PVAc matrix by sodium tetraborate (borax) and in-situ polymerization of vinyl acetate in the presence of CNCs [107]-[113]. Cellulose nanocrystals were successfully grafted by reversible addition-fragmentation chain transfer and macromolecular design via the interchange of xanthates polymerization (SI-RAFT/MADIX) of VAc in a controlled manner, as shown in Figure 3.

Chaabouni et al. investigated the effects of the addition of CNFs on the properties of waterborne polyvinyl acetate (PVA) adhesive [114]. A study investigated the effect of the addition of cellulose nanofibrils and nano clay on PVAc 


\section{Graft initiation:}

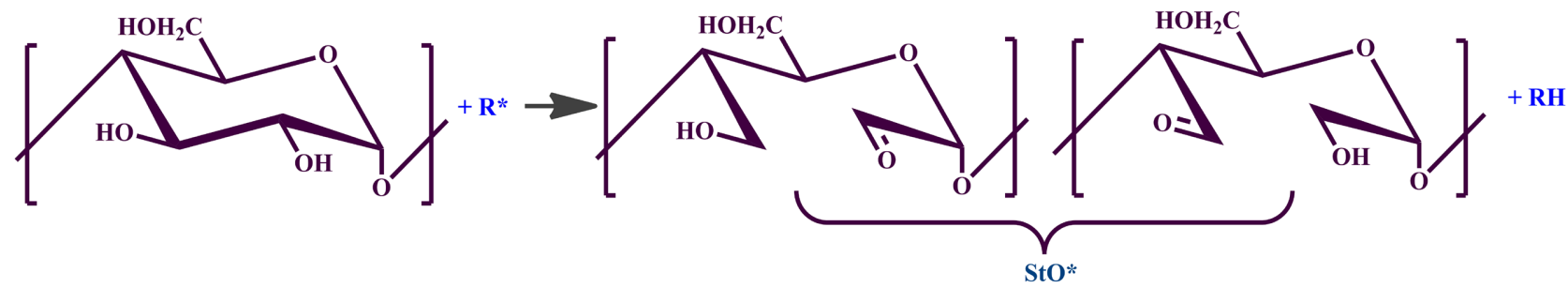

Graft propagation:

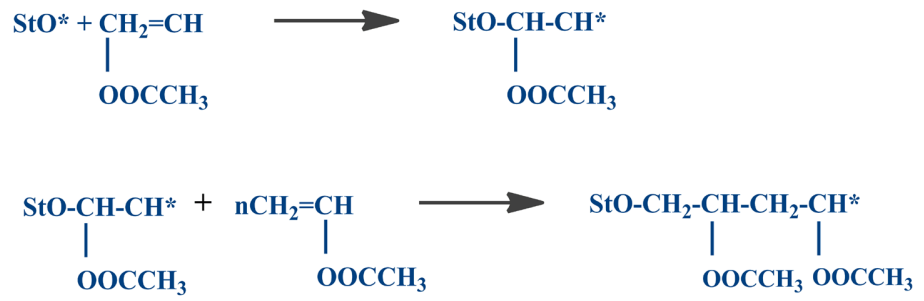

\section{Graft termination:}

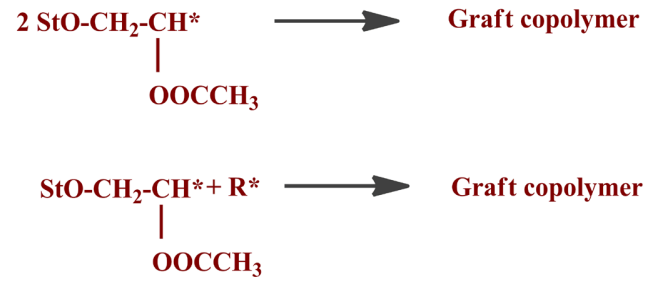

Figure 2. Vinyl acetate grafting on starch.

Immobilization of chain transfer agent (CTA) on cellulose nanocrystals $(\mathrm{CNC})$
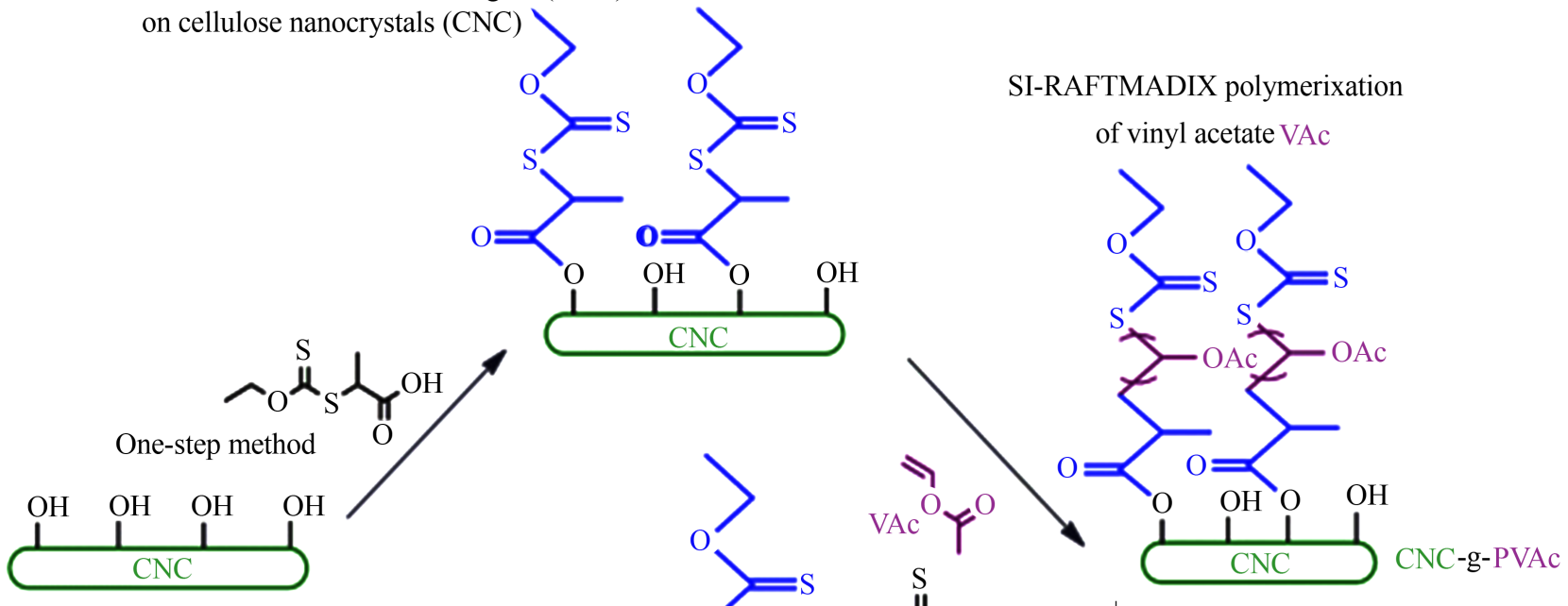

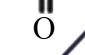

H
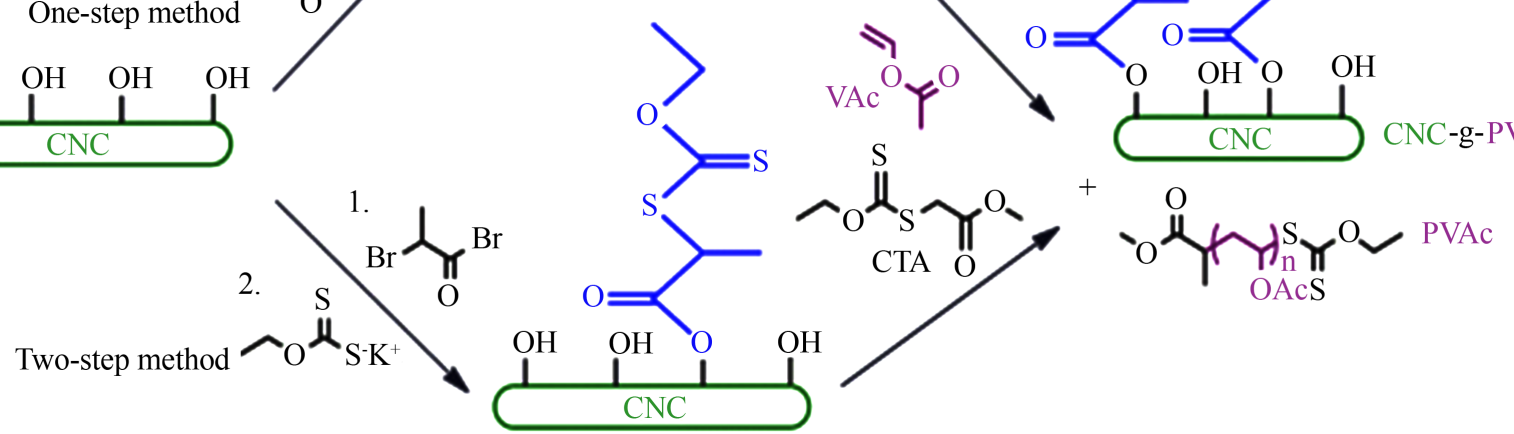

Figure 3. SI-RAFT/MADIX polymerization of vinyl acetate on cellulose nanocrystals. 
adhesive [115]. In the presence of CNC, a persulfate/metabisulfite initiator was employed for in-situ emulsion polymerization of VAc without any surfactant [116]-[121].

\section{Lignin based PVAc emulsions}

Recently, lignin has been copolymerized with some vinyl monomers via the graft-onto method, graft from, and click chemistry techniques [122]-[129]. These studies showed significant enhancement in the physical and thermal properties of the copolymers [130] [131]. Therefore, VAc was grafted onto lignin to prepare lignin-VAc monomer (LVAc), and later it was copolymerized with VAc monomer through a free-radical copolymerization, as shown in Figure 4.

In some studies, vinyl acetate was grafted from chitosan by emulsion polymerization to combine the excellent bonding properties of chitosan with the applicability of PVAc. The bonding performance was investigated by bonding thin wood veneers and measuring the tensile shear strength after conditioning. The resulting bonding performance of the chitosan-graft-PVAc adhesive was outstanding, especially regarding the wet strength of the bond line, which is superior to that of the com. benchmark PVAc-based wood adhesive [132].

\section{3) Water-resistant polyvinyl acetate emulsions}

However, PVA stabilized PVAc emulsion-based adhesives also have some defects, its cold tolerance, mechanical stability, thermal stability, and water resistance are poor. Till now, many studies have been done on this topic, including the preparation methods, radiation preparation, co-polymerization, co-blending, and so on [133]. PVAc water-resistant glues used in the wood industry and belonging to the class of durability D3 as per EN 204 - 205 show high resistance to both water and heat compared to the usual PVAc-based thermoplastic products. Conventionally synthesized adhesives are attained by cross-linking the linear PVA chains and using Lewis acid, such as aluminum chloride [134]-[140].

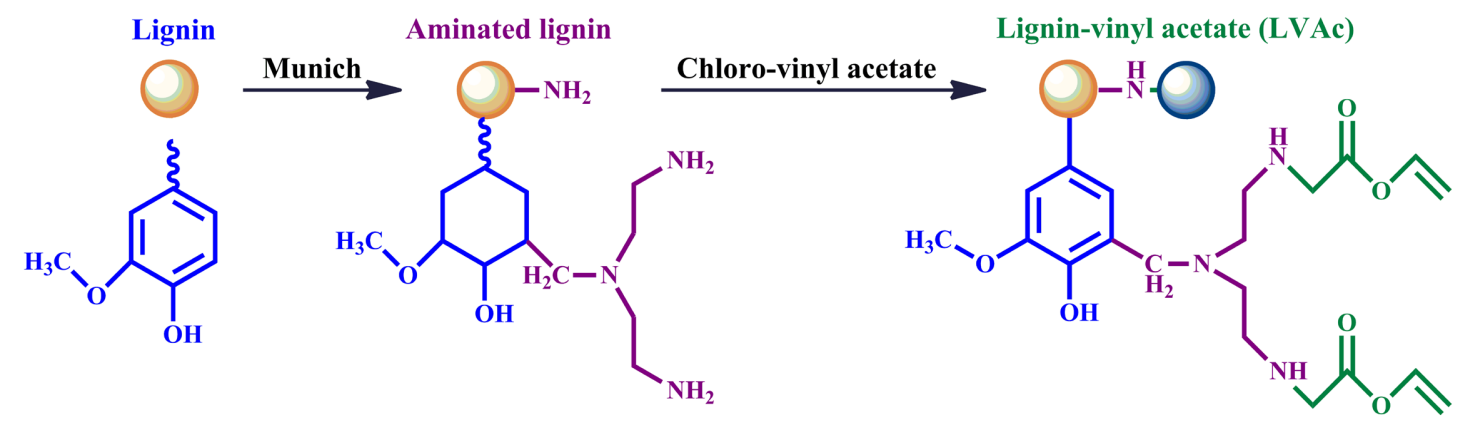

Vinyl acetate (VAc)
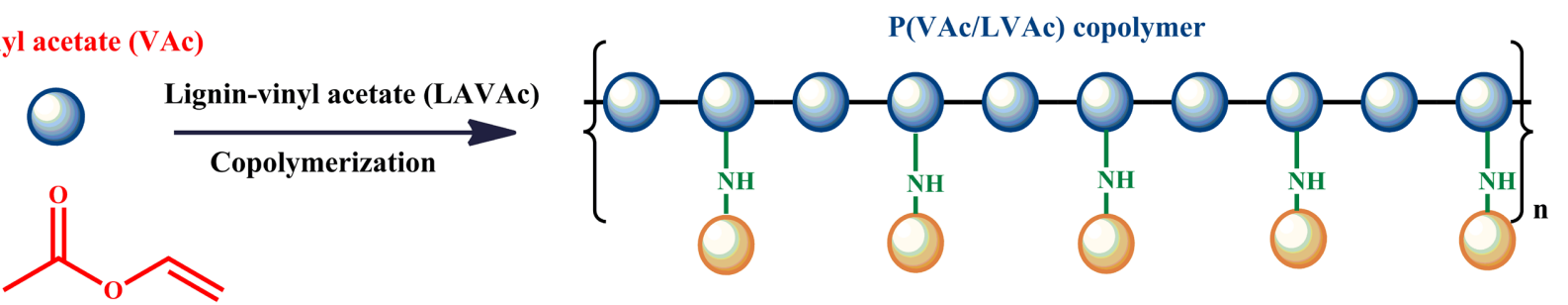

Figure 4. Schematic representation of the preparation of LVAc and its copolymer with VAc. 
Vinyl acetate- $N$-hydroxymethyl acrylamide copolymer emulsions

In some of the studies, to improve PVAc's chemical, physical, mechanical, and thermal properties, and active monomer named N-hydroxymethyl acrylamide (NMA) was introduced to modify PVAc based emulsion adhesives. Here, NMA was an amide derivative from unsaturated carboxylic acid, it could polymerize with VAc, and the cross-linkable thermosetting copolymer of PVAc-NMA could be obtained. The molecules could further get cross-linked and cured under suitable acidic conditions [140].

Crosslinking reactions

Usually, NMA shows the reaction mechanism of that cross-linking agent: two molecules of NMA condense through the hydroxyl-methyl groups by leaving one molecule of water to form bis-(acrylamide-methyl) ether and, in a second step, by releasing one molecule of formaldehyde to form N, N-methylene-bisacrylamide as shown in Figure 5. The reaction has been affected by acid catalysis or simply by heat [141]. As soon as the polymer dispersion is made, the product is modified by adding an external crosslinking agent able to act on the protective colloid (usually polyvinyl alcohol). The choice of this external agent is driven by the need to lower the $\mathrm{pH}$ of the system and, at the same time, block the hydrophilic action of the protective colloid, as shown in Figure 6 [142].

A new biodegradable, renewable, and environmentally friendly starch-based adhesive for wood-based panels was synthesized. The synthesis was conducted by grafting polymerization of vinyl acetate (VAC) monomer onto corn starch and crosslinking polymerization with NMA. Compared with the traditional starch-based wood adhesive, the water-resistance of starch-based adhesive with NMA was greatly improved [74] [92] [143]-[155].

\section{Acrylic comonomers based emulsions}

A recently developed, successful approach to achieving controlled thermosetting of PVAc emulsions involved novel polymer latex particles bearing functional groups introduced via the reactive monomer acetoacetoxyethyl methacrylate
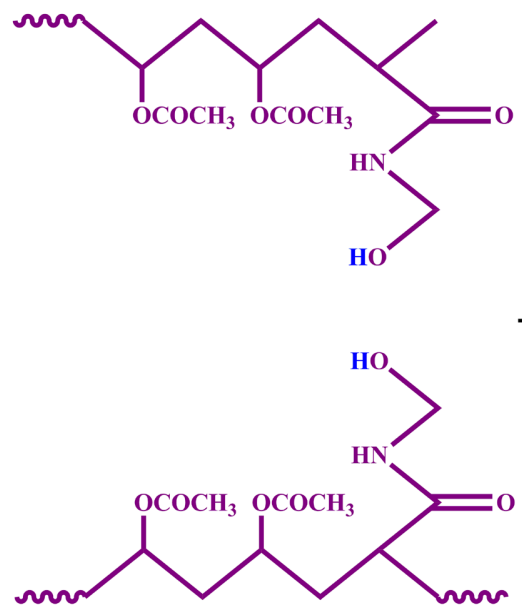

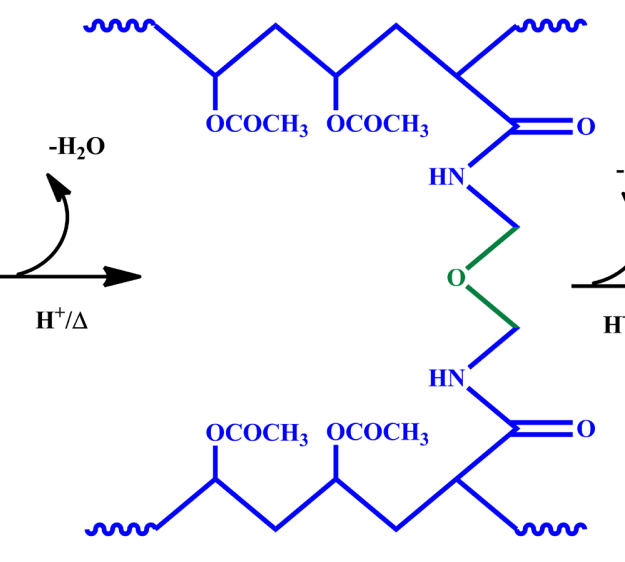

bis-(acrylamidomethyl)ether

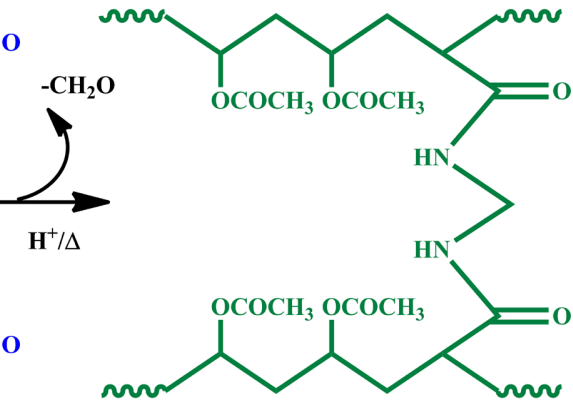

N-N'-methylenbisacrylamide

Figure 5. Cross-linking reaction of PVAc in the presence of N-methylolacrylamide (NMA mechanism). 


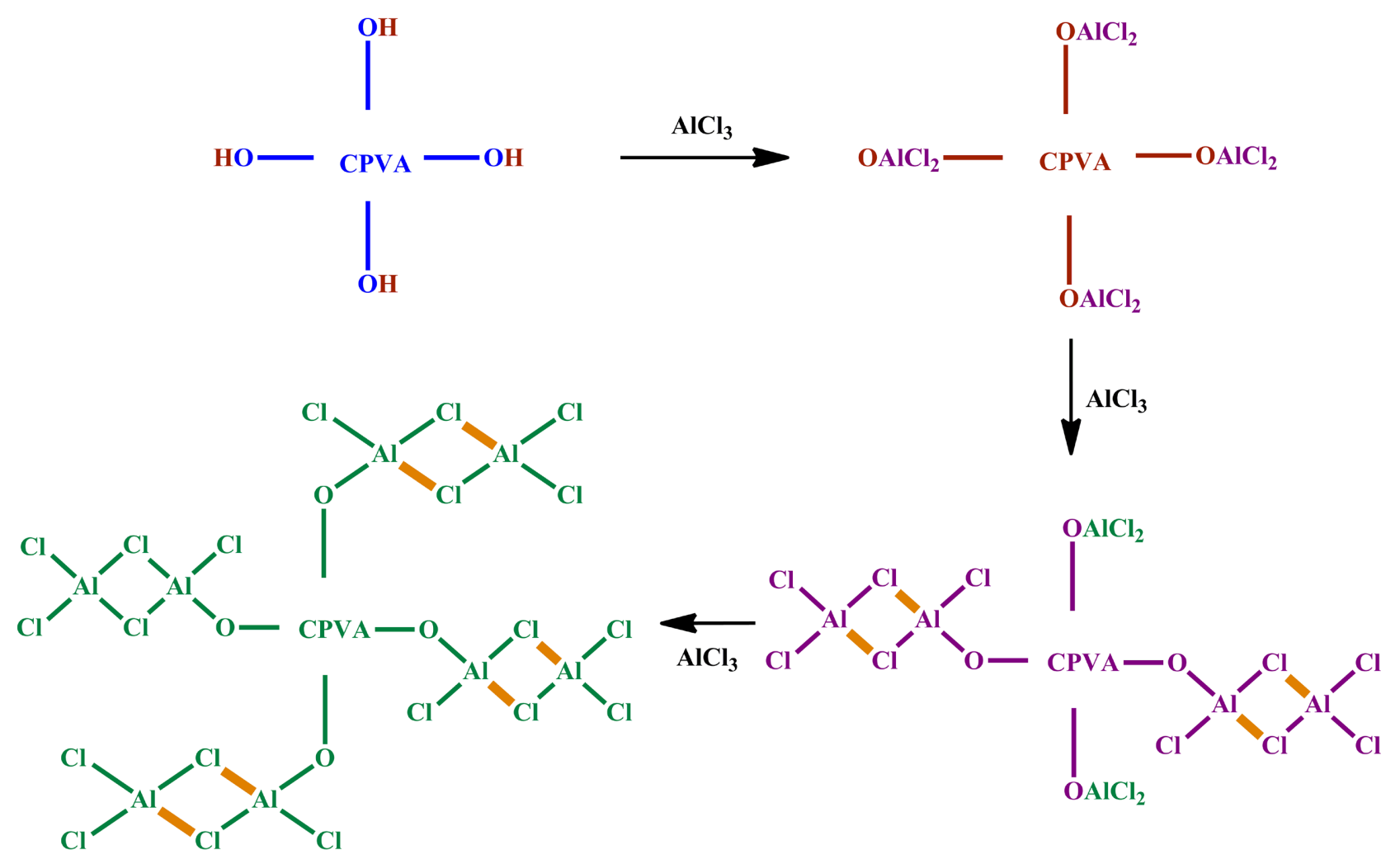

Figure 6. Reaction mechanism between the protective colloid and the external crosslinking agent.

(AAEM) which had been recognized for its ability to provide a versatile crosslinking site in thermoset adhesives [156]. To improve polyvinyl acetate emulsion adhesive's bonding strength and water resistance, a new kind of four component copolymer emulsion adhesive suited for plywood was prepared by semi-continuous emulsion polymerization with vinyl acetate, Bu acrylate, Me methacrylate, and acrylic acid as monomers [157] [158]. The invention further pertains to a dispersion incorporating said vinyl ester-based polymer latex composition, products comprising said dispersion, and various uses of the dispersion. A latex was prepared from acrylic acid, Bu acrylate, ethylene, $\mathrm{N}$-methylol acrylamide, sodium vinyl sulfonate, Veova 10, and vinyl acetate [159] [160] [161]. Water-resistant copolymer latexes of vinyl acetate (VAc)/vinyl ester of versatic acid (Veova)/methacrylic acid (MAA) were prepared by the semi-continuous seeding emulsion polymerization. The water resistance of these latexes was greatly dependent on the M AA content, the introduction method of MAA, and the neutralization degree of MAA [156] [158] [160] [162]. This paper aims to enhance the water resistance and the heat resistance of poly (vinyl acetate) (PVAc) emulsion adhesive by providing the emulsion with controllable thermosetting capability. Emulsion polymerization was used to synthesize PV Ac/Veova 10 copolymers with varying proportions of acetoacetoxyethyl methacrylate (AAEM) incorporated in the copolymer chains [163] [164]. Water-resistant copolymer latexes of vinyl acetate (VAc)/vinyl ester of versatic acid (Veova)/methacrylic acid (MAA) were prepared by the semi-continuous seeding emulsion polymerization. 
The water resistance of these latexes was greatly dependent on the MAA content, the introduction method of MAA, and the neutralization degree of MAA. The results showed that water-resistant VAc/Veova/MAA latex had 9.51 MPa of dry compression shear strength, $3.77 \mathrm{MPa}$ of wet compression shear strength, and $47.0 \%$ water absorption [162] [165] [166] [167] [168]. The experimental method of copolymerization of acrylic acid with vinyl acetate was introduced, and optimum technical conditions were determined. The modification improved the adhesive's shear strength and water resistance [169] [170].

Vinyl formal comonomer based emulsion

In some study, to improve the performance of PVAc (polyvinyl acetate), vinyl acetate white emulsion was modified by copolymerization with polyvinyl formal [171].

\section{Modified PVA stabilized emulsions}

The methods of improving water-resistance of PVAc emulsion are reviewed, mainly including copolymerization, addition of compounding agent and modification of protective colloid [172]. A study was conducted to determine whether the water-resistance of PVAc emulsion can be improved by using PVA as a protective colloid, in which an acetoacetyl group is introduced into the protective colloid. Compared with PVAc with generic PVA, the PVAc using acetoacetylated PVA produces good numerical values in film properties and lumber bonding capacity, thus exhibiting improved water resistance [173] [174] [175].

Vinyl acetate was polymerized in the presence of acetoacetylated PVA (acetoacetyl content $5.5 \mathrm{~mol} \%$; average saponification degree $99 \mathrm{~mol} \%$ ) and subsequently mixed with propionic hydrazide to give an emulsion. Then, one woodblock was coated with the emulsion, laminated with the other block, and compressed to provide a test sample showing compression shear adhesive strength $\geq$ $30 \mathrm{~kg} / \mathrm{cm}$ after boiling for $4 \mathrm{hr}$ [176]. With acetoacetyl polyvinyl alcohol (AA-PVA) as protective colloid, Butyl acrylate (BA) and vinyl versatate (Veova10) as modified comonomers of polyvinyl acetate (PVAc) emulsion, a modified PVAc emulsion adhesive was prepared. The research results showed that the corresponding modified PVAc emulsion had good shear strength and good water resistance [177].

\section{Silane modified PVAc emulsions}

The aqueous emulsion comprises a vinyl acetate copolymer with mol. wt. 1000 - 800,000, such as vinyl acetate-vinyltrimethoxysilane copolymer. The polyvinyl acetate aqueous emulsion is free of formalin and is either used alone or combined with an additional crosslinking agent to improve the water resistance [178] [179] [180]. Polyvinyl acetate was emulsion-polymerized in the presence of Gohsefimer Z 210, and Exceval RS 2117 as a protective colloid using hydrogen peroxide and 1-part glycidyloxypropyltrimethoxysilane was added therein to give an aqueous adhesive, showing good storage stability and adhesion [181].

\section{4) Blending with other crosslinkers}

Various approaches were taken to improve the water resistance of PVAc emulsion adhesives. The polymer films' tensile storage modulus and glass transi- 
tion temperature $(\mathrm{Tg})$ were measured using dynamic mechanical analysis to quantify the influence. The polymer films' gel fraction and swelling ratio were measured to evaluate internal crosslink density. A blending of the PVAc emulsions with melamine/urea/formaldehyde resin modified the water resistance considerably. The film had a high tensile storage modulus because of the formation of an interpenetrating network-type structure [181]. Starch was oxidized and then condensed with urea; then, the modified oxidized starch was blended with polyvinyl acetate emulsion synthesized in the laboratory to prepare the main agent of aqueous polymer isocyanate (API) adhesive for plywood. The new main agent of API has excellent economic profit and no pollution [182]. The influence of glyoxal on the water resistance of pine-pine and beech-beech wood compounds formed by adhesives based on vinyl acetate dispersion is studied. A noticeable increase in water resistance is observed for pine-pine compounds if the adhesive composite contains not only glyoxal but also aluminum chloride and "glyoxal" additives [183].

\section{5) Low temperature working polyvinyl acetate}

Some problems about typical PVAc emulsion's stability, freezing resistance, and flowability at low temperature were successfully solved by adding Butyl acrylate (BA) [184], Methyl methacrylate (MMA) [185] [186], acrylic acid (AA) [187] [188], and 2-Ethyl Hexa-acrylate [189] co-monomer with means of emulsion copolymerization using PVA as stabilizing and emulsifying agent [190]. The properties of copolymer emulsion have no significant changes after five freeze-thaw cycles, frozen for six months, even frozen-thawed alternatively for six months out of the warehouse. The emulsion also exhibits good flowability at $0^{\circ}$. It can be an excellent emulsion adhesive for porous materials [191] [192]. The adhesive does not generate low-temperature gel and has suitable construction properties and high low-temperature strength [193] [194].

\section{Conclusion}

Adhesive for wood bonding is not only key to the efficient utilization of wood; it has been a key factor in the development and growth of the forest products industry. Because of the importance of adhesives to the utilization of wood, it is expected that improvements in adhesive systems will continue to be made with considering health and safety aspects. Future areas for the advancement of Polyvinyl acetate adhesive systems will concentrate on increased water resistance, heat resistance, faster cure, applicability at low temperature, and based on sustainable raw material for the wood being bonded. For this review we used Scifinder as search engine to compile all the information on research trend in PVAc based wood adhesive. More researches should be carried out for adhesives along the following lines: 1) Studying the modification of polyvinyl acetate adhesives should be continued. Modified adhesives will have better properties and meet requirements under more harsh conditions like applicability at low temperatures. An important aspect will be to simplify the process of modification, reduce 
costs without affecting the performance properties with the help of new methods like core-shell polymerization and graft polymerization. 2) Developing natural polymer grafted adhesives. Developing environmentally friendly adhesives, low-cost, improved properties, and renewable raw materials have become increasingly essential.

\section{Conflicts of Interest}

The authors declare no conflicts of interest regarding the publication of this paper.

\section{References}

[1] Jakes, J.E., Frihart, C.R., Hunt, C.G., Yelle, D.J., Plaza, N.Z., Lorenz, L., Grigsby, W., Ching, D.J., Kamke, F., Gleber, S.-C., Vogt, S. and Xiao, X. (2019) X-Ray Methods to Observe and Quantify Adhesive Penetration into Wood. Journal of Materials Science, 54, 705-718. https://doi.org/10.1007/s10853-018-2783-5

[2] Ülker, O. (2016) Wood Adhesives and Bonding Theory. In: Rudawska, A., Ed., Adhesives-Applications and Properties, InTech, London.

https://doi.org/10.5772/65759

[3] Kaboorani, A. and Riedl, B. (2011) Improving Performance of Polyvinyl Acetate (PVA) as a Binder for Wood by Combination with Melamine Based Adhesives. International Journal of Adhesion and Adhesives, 31, 605-611.

https://doi.org/10.1016/j.ijadhadh.2011.06.007

[4] Vnučec, D., Goršek, A., Kutnar, A. and Mikuljan, M. (2015) Thermal Modification of Soy Proteins in the Vacuum Chamber and Wood Adhesion. Wood Science and Technology, 49, 225-239. https://doi.org/10.1007/s00226-014-0685-5

[5] Ciannamea, E.M., Stefani, P.M. and Ruseckaite, R.A. (2010) Medium-Density Particleboards from Modified Rice Husks and Soybean Protein Concentrate-Based Adhesives. Bioresource Technology, 101, 818-825. https://doi.org/10.1016/j.biortech.2009.08.084

[6] Navarrete, P., Pizzi, A., Bertaud, F. and Rigolet, S. (2011) Condensed Tannin Reactivity Inhibition by Internal Rearrangements: Detection by CP-MAS 13C NMR. Maderas. Ciencia y Tecnología, 13, 59-68. https://doi.org/10.4067/S0718-221X2011000100006

[7] Kim, S. (2009) Environment-Friendly Adhesives for Surface Bonding of Wood-Based Flooring Using Natural Tannin to Reduce Formaldehyde and TVOC Emission. Bioresource Technology, 100, 744-748. https://doi.org/10.1016/j.biortech.2008.06.062

[8] Pizzi, A. (2006) Recent Developments in Eco-Efficient Bio-Based Adhesives for Wood Bonding: Opportunities and Issues. Journal of Adhesion Science and Technology, 20, 829-846. https://doi.org/10.1163/156856106777638635

[9] Effendi, A., Gerhauser, H. and Bridgwater, A.V. (2008) Production of Renewable Phenolic Resins by Thermochemical Conversion of Biomass: A Review. Renewable \& Sustainable Energy Reviews, 12, 2092-2116. https://doi.org/10.1016/j.rser.2007.04.008

[10] Bradshaw, I.J. and Kennedy, J.F. (1985) Starch: Chemistry and Technology, 2nd Edition edited by R. L. Whistler, J. N. BeMiller and E. F. Paschall, Academic Press,

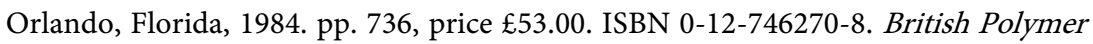


Journal, 17, 377-378. https://doi.org/10.1002/pi.4980170413

[11] Wang, Z., Li, Z., Gu, Z., Hong, Y. and Cheng, L. (2012) Preparation, Characterization and Properties of Starch-Based Wood Adhesive. Carbohydrate Polymers, 88, 699-706. https://doi.org/10.1016/j.carbpol.2012.01.023

[12] Athawale, V.D. and Lele, V. (2000) Thermal Studies on Granular Maize Starch and its Graft Copolymers with Vinyl Monomers. Starch, 52, 205-213. https://doi.org/10.1002/1521-379X(200007)52:6/7<205::AID-STAR205>3.0.CO;2-3

[13] Goñi, I., Gurruchaga, M., Valero, M. and Guzman, G.M. (1983) Graft Polymerization of Acrylic Monomers onto Starch Fractions. I. Effect of Reaction Time on Grafting Methyl Methacrylate onto Amylase. Journal of Polymer Science: Polymer Chemistry Edition, 21, 2573-2580. https://doi.org/10.1002/pol.1983.170210837

[14] Gurruchaga, M., Goñi, I., Valero, M. and Guzmán, G.M. (1992) Graft copoLymerization of Hydroxylic Methacrylates and Ethyl Acrylate onto Amylopectin. Polymer (Guildf), 33, 2860-2862. https://doi.org/10.1016/0032-3861(92)90467-B

[15] Kaewtatip, K. and Tanrattanakul, V. (2008) Preparation of Cassava Starch Grafted with Polystyrene by Suspension Polymerization. Carbohydrate Polymers, 73, 647-655. https://doi.org/10.1016/j.carbpol.2008.01.006

[16] Kim, S. and Kim, H.-J. (2006) Thermal Stability and Viscoelastic Properties of MF/PVAc Hybrid Resins on the Adhesion for Engineered Flooring in under Heating System; ONDOL. Thermochimica Acta, 444, 134-140.

https://doi.org/10.1016/j.tca.2006.03.009

[17] Meshram, M.W., Patil, V.V., Mhaske, S.T. and Thorat, B.N. (2009) Graft Copolymers of Starch and Its Application in Textiles. Carbohydrate Polymers, 75, 71-78. https://doi.org/10.1016/j.carbpol.2008.06.012

[18] Atanase, L.I., Bistac, S. and Riess, G. (2015) Effect of Poly(vinyl alcohol-co-vinyl acetate) Copolymer Blockiness on the Dynamic Interfacial Tension and Dilational Viscoelasticity of Polymer-Anionic Surfactant Complex at the Water-1-Chlorobutane Interface. Soft Matter, 11, 2665-2672. https://doi.org/10.1039/C4SM02766C

[19] Gadhave, R.V., Mahanwar, P.A. and Gadekar, P.T. (2017) Starch-Based Adhesives for Wood/Wood Composite Bonding: Review. Open Journal of Polymer Chemistry, 7, 19-32. https://doi.org/10.4236/ojpchem.2017.72002

[20] Lu, J., Easteal, A.J. and Edmonds, N.R. (2011) Crosslinkable Poly(vinyl acetate) Emulsions for Wood Adhesive. Pigment \& Resin Technology, 40, 161-168. https://doi.org/10.1108/03699421111130423

[21] Ranade, A., D’Souza, N.A. and Gnade, B. (2002) Exfoliated and Intercalated Polyamide-Imide Nanocomposites with Montmorillonite. Polymer (Guildf), 43, 3759-3766. https://doi.org/10.1016/S0032-3861(02)00106-4

[22] Stefani, P.M., Peña, C., Ruseckaite, R.A., Piter, J.C. and Mondragon, I. (2008) Processing Conditions Analysis of Eucalyptus globulus Plywood Bonded with Resol-Tannin Adhesives. Bioresource Technology, 99, 5977-5980. https://doi.org/10.1016/j.biortech.2007.10.013

[23] Roffael, E., Dix, B. and Okum, J. (2000) Use of Spruce Tannin as a Binder in Particleboards and Medium Density Fiberboards (MDF). Holz als Roh- und Werkstoff, 58, 301-305. https://doi.org/10.1007/s001070050432

[24] Nuryawan, A., Ridwansyah, Alamsyah, E.M. and Widyorini, R. (2020) Starch Based Adhesives Made from Durian Seed through Dextrinization. IOP Conference Series: Materials Science and Engineering, 801, Article ID: 012088.

https://doi.org/10.1088/1757-899X/801/1/012088 
[25] Li, Z., Wang, J., Li, C., Gu, Z., Cheng, L. and Hong, Y. (2015) Effects of Montmorillonite Addition on the Performance of Starch-Based Wood Adhesive. Carbohydrate Polymers, 115, 394-400. https://doi.org/10.1016/j.carbpol.2014.08.106

[26] Kinloch, A.J. (1987) Adhesion and Adhesives. Springer Netherlands, Dordrecht. https://doi.org/10.1007/978-94-015-7764-9

[27] Lerner, F. and Alon, M. (1987) Fractionation of Partly Hydrolyzed Polyvinyl Acetate. Journal of Polymer Science Part A: Polymer Chemistry, 25, 181-189. https://doi.org/10.1002/pola.1987.080250115

[28] Wang, Z., Gu, Z., Hong, Y., Cheng, L. and Li, Z. (2011) Bonding Strength and Water Resistance of Starch-Based Wood Adhesive Improved by Silica Nanoparticles. Carbohydrate Polymers, 86, 72-76. https://doi.org/10.1016/j.carbpol.2011.04.003

[29] Zeng, Y., Xu, P., Yang, W., Chu, H., Wang, W., Dong, W., Chen, M., Bai, H. and Ma, P. (2021) Soy Protein-Based Adhesive with Superior Bonding Strength and Water Resistance by Designing Densely Crosslinking Networks. European Polymer Journal, 142, Article ID: 110128. https://doi.org/10.1016/j.eurpolymj.2020.110128

[30] Morales, R., Martínez, K.D., Ruiz-Henestrosa, V.M.P. and Pilosof, A.M.R. (2015) Modification of Foaming Properties of Soy Protein Isolate by High Ultrasound Intensity: Particle Size Effect. Ultrasonics Sonochemistry, 26, 48-55. https://doi.org/10.1016/j.ultsonch.2015.01.011

[31] Hettiarachchy, N.S., Kalapathy, U. and Myers, D.J. (1995) Alkali-Modified Soy Protein with Improved Adhesive and Hydrophobic Properties. Journal of the American Oil Chemists' Society, 72, 1461-1464. https://doi.org/10.1007/BF02577838

[32] Gadhave, R.V., Mahanwar, P.A. and Gadekar, P.T. (2019) Study on Various Compositions of Polyvinyl Alcohol and Starch Blends by Cross-Linking with Glyoxal. Open Journal of Polymer Chemistry, 9, 76-85. https://doi.org/10.4236/ojpchem.2019.94007

[33] Moubarik, A., Allal, A., Pizzi, A., Charrier, F. and Charrier, B. (2010) Preparation and Mechanical Characterization of Particleboard Made from Maritime Pine and Glued with Bio-Adhesives Based on Cornstarch and Tannins. Maderas. Ciencia $y$ Tecnología, 12, 189-197. https://doi.org/10.4067/S0718-221X2010000300004

[34] Weakley, F.B., Carr, M.E. and Mehltretter, C.L. (1972) Dialdehyde Starch in Paper Coatings Containing Soy Flour-Isolated Soy Protein Adhesive. Starch, 24, 191-194. https://doi.org/10.1002/star.19720240604

[35] Wu, Y.B., Lv, C.F. and Han, M.N. (2009) Synthesis and Performance Study of Polybasic Starch Graft Copolymerization Function Materials. Advanced Materials Research, 79-82, 43-46. https://doi.org/10.4028/www.scientific.net/AMR.79-82.43

[36] Skeist, I., Ed. (1990) Handbook of Adhesives. Springer US, Boston, MA. https://doi.org/10.1007/978-1-4613-0671-9

[37] Huang, J. and Li, K. (2008) A New Soy Flour-Based Adhesive for Making Interior Type II Plywood. Journal of the American Oil Chemists' Society, 85, 63-70. https://doi.org/10.1007/s11746-007-1162-1

[38] Sotayo, A., Bradley, D.F., Bather, M., Oudjene, M., El-Houjeyri, I. and Guan, Z. (2020) Development and Structural Behaviour of Adhesive Free Laminated Timber Beams and Cross Laminated Panels. Construction and Building Materials, 259, Article ID: 119821. https://doi.org/10.1016/j.conbuildmat.2020.119821

[39] Li, X., Guan, P. and Liu, Y. (n.d.) Environmentally Friendly Starch-Modified Polyvinyl Alcohol Adhesives for Construction and Preparation Method Thereof. CN103897639. 
[40] Bangham, D.H. and Razouk, R.I. (1937) Adsorption and the Wettability of Solid Surfaces. Transactions of the Faraday Society, 33, 1459-1463. https://doi.org/10.1039/tf9373301459

[41] Gu, J.Y., Zuo, Y.F., Zhang, Y.H., Tan, H.Y., Zhu, L.B. and Shen, J. (2010) Preparation of Plywood Using Starch Adhesives Modified with Isocyanate. Applied Mechanics and Materials, 26-28, 1065-1068. https://doi.org/10.4028/www.scientific.net/AMM.26-28.1065

[42] Gao, Z., Wang, W., Zhao, Z. and Guo, M. (2011) Novel Whey Protein-Based Aqueous Polymer-Isocyanate Adhesive for Glulam. Journal of Applied Polymer Science, 120, 220-225. https://doi.org/10.1002/app.33025

[43] Özcan, C., Uysal, B., Kurt, Ş. and Esen, R. (2013) Effect of Dowels and Adhesive Types on Withdrawal Strength in Particleboard and MDF. Journal of Adhesion Science and Technology, 27, 843-854. https://doi.org/10.1080/01694243.2012.727157

[44] Wang, Z., Gu, Z., Li, Z., Hong, Y. and Cheng, L. (2013) Effects of Emulsifier on the Bonding Performance and Freeze-Thaw Stability of Starch-Based Wood Adhesive. Cellulose, 20, 2583-2590. https://doi.org/10.1007/s10570-013-9984-5

[45] Lu, D., Xiao, C. and Sun, F. (2012) Controlled Grafting of Poly(vinyl acetate) onto Starch via RAFT Polymerization. Journal of Applied Polymer Science, 124, 3450-3455. https://doi.org/10.1002/app.35423

[46] Kim, S. and Kim, H.-J. (2006) Study of Miscibility of Melamine-Formaldehyde Resin and Poly(vinyl acetate) Blends for Use as Adhesives in Engineered Flooring. Journal of Adhesion Science and Technology, 20, 209-219. https://doi.org/10.1163/156856106775897739

[47] Gadhave, R.V., Srivastava, S., Mahanwar, P.A. and Gadekar, P.T. (2019) Lignin: Renewable Raw Material for Adhesive. Open Journal of Polymer Chemistry, 9, 27-38. https://doi.org/10.4236/ojpchem.2019.92003

[48] Gadhave, R.V., Mahanwar, P.A. and Gadekar, P.T. (2018) Starch Stabilized Polyvinyl Acetate Emulsion: Review. Polymers from Renewable Resources, 9, 75-84. https://doi.org/10.1177/204124791800900203

[49] Qiao, L. and Easteal, A.J. (2001) Aspects of the Performance of PVAc Adhesives in Wood Joints. Pigment \& Resin Technology, 30, 79-87. https://doi.org/10.1108/03699420110381599

[50] Cui, H.-W., Fang, Q. and Du, G.-B. (2014) Dynamic Mechanical and Thermal Kinetics of Polyvinyl Acetate Type Emulsions from Vinyl Acetate, N-Hydroxymethyl Acrylamide, and Montmorillonite. Advances in Polymer Technology, 33, Article ID: 21393. https://doi.org/10.1002/adv.21393

[51] Chiozza, F. and Pizzo, B. (2016) Innovation in Poly(vinyl acetate) Water Resistant D3 Glues Used in Wood Industry. International Journal of Adhesion and Adhesives, 70, 102-109. https://doi.org/10.1016/j.ijadhadh.2016.06.003

[52] Qiao, L., Coveny, P.K. and Easteal, A.J. (2002) Modifications of Poly(vinyl alcohol) for Use in Poly(vinyl acetate) Emulsion Wood Adhesives. Pigment \& Resin Technology, 31, 88-95. https://doi.org/10.1108/03699420210420378

[53] Gonzalez, G.S.M., Dimonie, V.L., Sudol, E.D., Yue, H.J., Klein, A. and El-Aasser, M.S. (1996) Characterization of Poly(vinyl alcohol) during the Emulsion Polymerization of Vinyl Acetate Using Poly(vinyl alcohol) as Emulsifier. Journal of Polymer Science Part A: Polymer Chemistry, 34, 849-862.

https://doi.org/10.1002/(SICI)1099-0518(19960415)34:5<849::AID-POLA14>3.0.C $\underline{\mathrm{O} ; 2-\mathrm{I}}$ 
[54] Nakamae, M., Yuki, K., Sato, T. and Maruyama, H. (1999) Preparation of Polymer Emulsions Using a Poly(vinyl alcohol) as Protective Colloid. Colloids and Surfaces A: Physicochemical and Engineering Aspects, 153, 367-372. https://doi.org/10.1016/S0927-7757(98)00458-0

[55] Fagbemi, O.D. and Sithole, B. (2021) Evaluation of Waste Chicken Feather Protein Hydrolysate as a Bio-Based Binder for Particleboard Production. Current Research in Green and Sustainable Chemistry, 4, Article ID: 100168. https://doi.org/10.1016/j.crgsc.2021.100168

[56] Mori, A., Kitayama, T., Takatani, M. and Okamoto, T. (2004) A Honeymoon-Type Adhesive for Wood Products Based on Acetoacetylated Poly(vinyl alcohol) and Diamines: Effect of Diamines and Degree of Acetoacetylation. Journal of Applied Polymer Science, 91, 2966-2972. https://doi.org/10.1002/app.13491

[57] Fang, Q., Cui, H.-W. and Du, G.-B. (2013) Preparation and Characterization of PVAc-NMA-MMT. Journal of Thermoplastic Composite Materials, 26, 1393-1406. https://doi.org/10.1177/0892705712461644

[58] Cui, H.-W. and Du, G.-B. (2013) Development of Novel Polymers Prepared by Vinyl Acetate and N-Hydroxymethyl Acrylamide. Journal of Thermoplastic Composite Materials, 26, 762-776. https://doi.org/10.1177/0892705711429165

[59] Kaboorani, A. and Riedl, B. (2011) Effects of Adding Nano-Clay on Performance of Polyvinyl Acetate (PVA) as a Wood Adhesive. Composites Part A: Applied Science and Manufacturing, 42, 1031-1039.

https://doi.org/10.1016/j.compositesa.2011.04.007

[60] Mahrdt, E., Pinkl, S., Schmidberger, C., van Herwijnen, H.W.G., Veigel, S. and Gindl-Altmutter, W. (2016) Effect of Addition of Microfibrillated Cellulose to Urea-Formaldehyde on Selected Adhesive Characteristics and Distribution in Particle Board. Cellulose, 23, 571-580. https://doi.org/10.1007/s10570-015-0818-5

[61] Veigel, S., Rathke, J., Weigl, M. and Gindl-Altmutter, W. (2012) Particle Board and Oriented Strand Board Prepared with Nanocellulose-Reinforced Adhesive. Journal of Nanomaterials, 2012, Article ID: 158503. https://doi.org/10.1155/2012/158503

[62] Gadhave, R.V., Mahanwar, P.A., Gadekar, P.T. and Kasbe, P.S. (2020) A Study on the Effect of Starch-Polyvinyl Alcohol Blends by Addition of Citric Acid and Boric Acid for Enhancement in Performance Properties of Polyvinyl Acetate-Based Wood Adhesive. Journal of the Indian Academy of Wood Science, 17, 9-20. https://doi.org/10.1007/s13196-019-00249-6

[63] Bonnefond, A., Reyes, Y., Peruzzo, P., Ronne, E., Fare, J., Paulis, M. and Leiza, J.R. (2013) Effect of the Incorporation of Modified Silicas on the Final Properties of Wood Adhesives. Macromolecular Reaction Engineering, 7, 527-537.

https://doi.org/10.1002/mren.201300117

[64] Ma, C.-C.M., Wu, H.-D., Chu, P.P. and Tseng, H.-T. (1997) Prediction of Thermodynamic Properties of Novolak-Type Phenolic Resin and Aliphatic Polyester Blends: Painter-Coleman Association Model Study of Compositional Homogeneity. Macromolecules, 30, 5443-5449. https://doi.org/10.1021/ma961251o

[65] Gardner, D.J., Oporto, G.S., Mills, R. and Samir, M.A.S.A. (2008) Adhesion and Surface Issues in Cellulose and Nanocellulose. Journal of Adhesion Science and Technology, 22, 545-567. https://doi.org/10.1163/156856108X295509

[66] Kim, S. and Kim, H.-J. (2005) Effect of Addition of Polyvinyl Acetate to Melamine-Formaldehyde Resin on the Adhesion and Formaldehyde Emission in Engineered Flooring. International Journal of Adhesion and Adhesives, 25, 456-461. https://doi.org/10.1016/j.ijadhadh.2005.01.001 
[67] Petkovi, G., Preproti, S.P. and Bani, D. (2017) Evaluation of Finished Product Quality Depeding on Paper Properties and Binding Technique. Politehnika i Dizajn, 5, 237-247.

[68] Wen, N., Tang, Q., Chen, M. and Wu, L. (2008) Synthesis of PVAc/SiOz Latices Stabilized by Silica Nanoparticles. Journal of Colloid and Interface Science, 320, 152-158. https://doi.org/10.1016/j.jcis.2007.11.059

[69] Petrie, E.M. (n.d.) Bookbinding Adhesives. Adhesives \& Sealants Industry. https://www.adhesivesmag.com/articles/87133-bookbinding-adhesives

[70] Willett, J.L. and Finkenstadt, V.L. (2006) Reactive Extrusion of Starch-Polyacrylamide Graft Copolymers Using Various Starches. Journal of Polymers and the Environment, 14, 125-129. https://doi.org/10.1007/s10924-006-0002-y

[71] Thomson, P. (2014) Book Binding Tutorial: Glues-Tips, Techniques, Types \& Recipes. iBookBinding, Bookbinding Tutorials \& Resources. https://www.ibookbinding.com/blog/bookbinding-gluing-tips-techniques-types-inf o/

[72] Rebsamen, W. (1983) Adhesive Binding Methods and Techniques. In Book Production Industry, March 1978.

[73] Paris, J. (2000) Adhesives for Paper, Board and Foils. International Journal of Adhesion and Adhesives, 20, 89-90. https://doi.org/10.1016/S0143-7496(99)00052-4

[74] Packham, D.E., Ed. (2005) Handbook of Adhesion. John Wiley \& Sons, Ltd., Chichester. https://doi.org/10.1002/0470014229

[75] Kiatkamjornwong, S., Mongkolsawat, K. and Sonsuk, M. (2002) Synthesis and Property Characterization of Cassava Starch Grafted Poly[acrylamide-co-(maleic acid)] Superabsorbent via $\gamma$-Irradiation. Polymer (Guildf), 43, 3915-3924. https://doi.org/10.1016/S0032-3861(02)00224-0

[76] Grüneberger, F., Künniger, T., Zimmermann, T. and Arnold, M. (2014) Rheology of Nanofibrillated Cellulose/Acrylate Systems for Coating Applications. Cellulose, 21, 1313-1326. https://doi.org/10.1007/s10570-014-0248-9

[77] Liu, X., Fan, X.-D., Tang, M.-F. and Nie, Y. (2008) Synthesis and Characterization of Core-Shell Acrylate Based Latex and Study of Its Reactive Blends. International Journal of Molecular Sciences, 9, 342-354. https://doi.org/10.3390/ijms9030342

[78] Liu, X., Zhang, X., Long, K., Zhu, X., Yang, J., Wu, Y., Luo, S. and Yang, S. (2012) PVA Wood Adhesive Modified with Sodium Silicate Cross-Linked Copolymer. Proceedings of 2012 International Conference on Biobase Material Science and Engineering, Changsha, 21-23 October 2012, 108-111. https://doi.org/10.1109/BMSE.2012.6466192

[79] Voitovich, V.A. (2010) Curing Agents of Silicate Based Adhesives. Polymer Science, Series D, 3, 174-176. https://doi.org/10.1134/S1995421210030032

[80] Huang, M.-W., Kuo, S.-W., Wu, H.-D., Chang, F.-C. and Fang, S.-Y. (2002) Miscibility and Hydrogen Bonding in Blends of Poly(vinyl acetate) with Phenolic Resin. Polymer (Guildf), 43, 2479-2487. https://doi.org/10.1016/S0032-3861(02)00007-1

[81] López-Suevos, F. and Frazier, C.E. (2006) Fracture Cleavage Analysis of PVAc Latex Adhesives: Influence of Phenolic Additives. Holzforschung, 60, 313-317.

https://doi.org/10.1515/HF.2006.050

[82] López-Suevos, F. and Frazier, C.E. (2006) Rheology of Latex Films Bonded to Wood: Influence of Cross-Linking. Holzforschung, 60, 47-52. https://doi.org/10.1515/HF.2006.009

[83] Fanta, G.F., Felker, F.C. and Shogren, R.L. (2004) Graft Polymerization of Acrylo- 
nitrile onto Spherocrystals Formed from Jet Cooked Cornstarch. Carbohydrate Polymers, 56, 77-84. https://doi.org/10.1016/j.carbpol.2003.12.004

[84] Jorfi, M. and Foster, E.J. (2015) Recent Advances in Nanocellulose for Biomedical Applications. Journal of Applied Polymer Science, 132.

https://doi.org/10.1002/app.41719

[85] Lei, H., Du, G., Pizzi, A. and Celzard, A. (2008) Influence of Nanoclay on Urea-Formaldehyde Resins for Wood Adhesives and Its Model. Journal of Applied Polymer Science, 109, 2442-2451. https://doi.org/10.1002/app.28359

[86] Trache, D., Tarchoun, A.F., Derradji, M., Hamidon, T.S., Masruchin, N., Brosse, N. and Hussin, M.H. (2020) Nanocellulose: From Fundamentals to Advanced Applications. Frontiers in Chemistry, 8, Article 392. https://doi.org/10.3389/fchem.2020.00392

[87] Jiang, G. and Cai, L. (n.d.) Montmorillonite-Modified PVAc Adhesive, and Preparation Method Thereof. CN109796915.

[88] Xu, M. (n.d.) Polyvinyl Acetate Emulsion Adhesive Incremental Additive and Its Manufacture Process. CN102660204.

[89] Taghiyari, H.R., Majidi, R. and Jahangiri, A. (2016) Adsorption of Nanowollastonite on Cellulose Surface: Effects on Physical and Mechanical Properties of Medium-Density Fiberboard (MDF). Cerne, 22, 215-222. https://doi.org/10.1590/0104776020162222146

[90] Liu, J., Howard, G.D., Lewis, S.H., Barros, M.D. and Stansbury, J.W. (2012) A Study of Shrinkage Stress Reduction and Mechanical Properties of Nanogel-Modified Resin Systems. European Polymer Journal, 48, 1819-1828. https://doi.org/10.1016/j.eurpolymj.2012.08.009

[91] Stöckel, F., Konnerth, J., Moser, J., Kantner, W. and Gindl-Altmutter, W. (2012) Micromechanical Properties of the Interphase in pMDI and UF Bond Lines. Wood Science and Technology, 46, 611-620. https://doi.org/10.1007/s00226-011-0432-0

[92] Frihart, C.R. (2009) Adhesive Groups and How They Relate to the Durability of Bonded Wood. Journal of Adhesion Science and Technology, 23, 601-617. https://doi.org/10.1163/156856108X379137

[93] Gaaz, T., Sulong, A., Akhtar, M., Kadhum, A., Mohamad, A. and Al-Amiery, A. (2015) Properties and Applications of Polyvinyl Alcohol, Halloysite Nanotubes and Their Nanocomposites. Molecules, 20, 22833-22847. https://doi.org/10.3390/molecules201219884

[94] Lou, Y. and Shang, S. (n.d.) One Kind of Nanosilica-Containing Reinforced Modified Polyvinyl Acetate Emulsion Adhesive for Pencil and Preparation Method Thereof. CN104974690.

[95] Chen, L., Xiong, Z., Xiong, H., Wang, Z., Din, Z., Nawaz, A., Wang, P. and Hu, C. (2018) Effects of $\mathrm{Nano}^{-\mathrm{TiO}_{2}}$ on Bonding Performance, Structure Stability and Film-Forming Properties of Starch-g-VAc Based Wood Adhesive. Carbohydrate Polymers, 200, 477-486. https://doi.org/10.1016/j.carbpol.2018.08.023

[96] Mapari, S., Mestry, S. and Mhaske, S.T. (2021) Developments in Pressure-Sensitive Adhesives: A Review. Polymer Bulletin, 78, 4075-4108. https://doi.org/10.1007/s00289-020-03305-1

[97] Gadhave, R.V., Mahanwar, P.A. and Gadekar, P.T. (2017) Factor Affecting Gel Time/Process-Ability of Urea Formaldehyde Resin Based Wood Adhesives. Open Journal of Polymer Chemistry, 7, 33-42. https://doi.org/10.4236/ojpchem.2017.72003 
[98] Jiang, W., Tomppo, L., Pakarinen, T., Sirviö, J.A., Liimatainen, H. and Haapala, A.T. (2018) Effect of Cellulose Nanofibrils on the Bond Strength of Polyvinyl Acetate and Starch Adhesives for Wood. BioResources, 13, 2283-2292. https://doi.org/10.15376/biores.13.2.2283-2292

[99] Fanta, G.F., Burr, R.C., Doane, W.M. and Russell, C.R. (1979) Graft Polymerization of Vinyl Acetate onto Starch. Saponification to Starch-g-Poly(vinyl alcohol). Journal of Applied Polymer Science, 23, 229-240. https://doi.org/10.1002/app.1979.070230121

[100] Din, Z.U., Xiong, H., Wang, Z., Chen, L., Ullah, I., Fei, P. and Ahmad, N. (2018) Effects of Different Emulsifiers on the Bonding Performance, Freeze-Thaw Stability and Retrogradation Behavior of the Resulting High Amylose Starch-Based Wood Adhesive. Colloids and Surfaces A: Physicochemical and Engineering Aspects, 538, 192-201. https://doi.org/10.1016/j.colsurfa.2017.11.002

[101] Matveev, Y., van Soest, J.J., Nieman, C., Wasserman, L., Protserov, V., Ezernitskaja, M. and Yuryev, V. (2001) The Relationship between Thermodynamic and Structural Properties of Low and High Amylose Maize Starches. Carbohydrate Polymers, 44, 151-160. https://doi.org/10.1016/S0144-8617(00)00211-3

[102] Chen, J. and Chen, J. (2001) Starch-Based White Adhesive Emulsion. CN1283661.

[103] Liu, L. (n.d.) Preparation of Starch-Modified Latex for Latex-Based Adhesive. CN101993671.

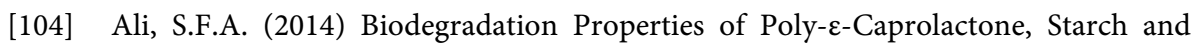
Cellulose Acetate Butyrate Composites. Journal of Polymers and the Environment, 22, 359-364. https://doi.org/10.1007/s10924-014-0675-6

[105] Gu, Y., Cheng, L., Gu, Z., Hong, Y., Li, Z. and Li, C. (2019) Preparation, Characterization and Properties of Starch-Based Adhesive for Wood-Based Panels. International Journal of Biological Macromolecules, 134, 247-254. https://doi.org/10.1016/j.ijbiomac.2019.04.088

[106] Pape, P.G. (2011) Adhesion Promoters: Silane Coupling Agents. In: Kutz, M., Ed., Applied Plastics Engineering Handbook, Elsevier, William Andrew, Norwich, NY, 503-517. https://doi.org/10.1016/B978-1-4377-3514-7.10029-7

[107] Zhang, Y., Pang, B., Yang, S., Fang, W., Yang, S., Yuan, T.-Q. and Sun, R.-C. (2018) Improvement in Wood Bonding Strength of Poly(vinyl acetate-butyl acrylate) Emulsion by Controlling the Amount of Redox Initiator. Materials (Basel), 11, Article 89. https://doi.org/10.3390/ma11010089

[108] Averous, L. (2000) Properties of Thermoplastic Blends: Starch-Polycaprolactone. Polymer (Guildf), 41, 4157-4167. https://doi.org/10.1016/S0032-3861(99)00636-9

[109] Agarwal, M., Koelling, K.W. and Chalmers, J.J. (1998) Characterization of the Degradation of Polylactic Acid Polymer in a Solid Substrate Environment. Biotechnology Progress, 14, 517-526. https://doi.org/10.1021/bp980015p

[110] Moon, R.J., Martini, A., Nairn, J., Simonsen, J. and Youngblood, J. (2011) Cellulose Nanomaterials Review: Structure, Properties and Nanocomposites. Chemical Society Reviews, 40, 3941-3994. https://doi.org/10.1039/c0cs00108b

[111] Khan, U., May, P., Porwal, H., Nawaz, K. and Coleman, J.N. (2013) Improved Adhesive Strength and Toughness of Polyvinyl Acetate Glue on Addition of Small Quantities of Graphene. ACS Applied Materials \& Interfaces, 5, 1423-1428. https://doi.org/10.1021/am302864f

[112] Kajtna, J. and Šebenik, U. (2017) Novel Acrylic/Nanocellulose Microsphere with Improved Adhesive Properties. International Journal of Adhesion and Adhesives, 74, 100-106. https://doi.org/10.1016/j.ijadhadh.2016.11.013 
[113] Boujemaoui, A., Mazières, S., Malmström, E., Destarac, M. and Carlmark, A. (2016) SI-RAFT/MADIX Polymerization of Vinyl Acetate on Cellulose Nanocrystals for Nanocomposite Applications. Polymer (Guildf), 99, 240-249. https://doi.org/10.1016/j.polymer.2016.07.013

[114] Kaboorani, A., Riedl, B., Blanchet, P., Fellin, M., Hosseinaei, O. and Wang, S. (2012) Nanocrystalline Cellulose (NCC): A Renewable Nano-Material for Polyvinyl Acetate (PVA) Adhesive. European Polymer Journal, 48, 1829-1837. https://doi.org/10.1016/j.eurpolymj.2012.08.008

[115] Chaabouni, O. and Boufi, S. (2017) Cellulose Nanofibrils/Polyvinyl Acetate Nanocomposite Adhesives with Improved Mechanical Properties. Carbohydrate Polymers, 156, 64-70. https://doi.org/10.1016/j.carbpol.2016.09.016

[116] Aydemir, D., Gündüz, G., Aşık, N. and Wang, A. (2016) The Effects of Poly(vinyl acetate) Filled with Nanoclay and Cellulose Nanofibrils on Adhesion Strength of Poplar and Scots Pine Wood. Drvna Industrija, 67, 17-24.

https://doi.org/10.5552/drind.2016.1441

[117] Ben Mabrouk, A., Dufresne, A. and Boufi, S. (2020) Cellulose Nanocrystal as Ecofriendly Stabilizer for Emulsion Polymerization and Its Application for Waterborne Adhesive. Carbohydrate Polymers, 229, Article ID: 115504.

https://doi.org/10.1016/j.carbpol.2019.115504

[118] Dhawale, P.V., Vineeth, S.K., Gadhave, R.V. and Mahanwar, P.A. (2021) Cellulose Stabilized Polyvinyl Acetate Emulsion: Review. Open Journal of Organic Polymer Materials, 11, 51-66. https://doi.org/10.4236/ojopm.2021.112002

[119] Wang, S., Chen, L. and Tong, Y. (2006) Structure-Property Relationship in Chitosan-Based Biopolymer/Montmorillonite Nanocomposites. Journal of Polymer Science Part A: Polymer Chemistry, 44, 686-696. https://doi.org/10.1002/pola.20941

[120] Mancini, E., Antonelli, M.G., Zobel, P.B. and Sasso, M. (2019) Characterization and Analytical Parametrization of Composite in Cellulose Fibre and PVA Matrix. Composites Part B: Engineering, 172, 496-505. https://doi.org/10.1016/j.compositesb.2019.05.093

[121] Rhim, J.-W. and Ng, P.K.W. (2007) Natural Biopolymer-Based Nanocomposite Films for Packaging Applications. Critical Reviews in Food Science and Nutrition, 47, 411-433. https://doi.org/10.1080/10408390600846366

[122] Dastjerdi, Z., Cranston, E.D. and Dubé, M.A. (2017) Synthesis of Poly(n-butyl acrylate/methyl methacrylate)/CNC Latex Nanocomposites via In Situ Emulsion Polymerization. Macromolecular Reaction Engineering, 11, Article ID: 1700013. https://doi.org/10.1002/mren.201700013

[123] Guilbert, S., Cuq, B. and Gontard, N. (1997) Recent Innovations in Edible and/or Biodegradable Packaging Materials. Food Additives \& Contaminants, 14, 741-751. https://doi.org/10.1080/02652039709374585

[124] Kong, F., Wang, S., Price, J.T., Konduri, M.K.R. and Fatehi, P. (2015) Water Soluble Kraft Lignin-Acrylic Acid Copolymer: Synthesis and Characterization. Green Chemistry, 17, 4355-4366. https://doi.org/10.1039/C5GC00228A

[125] Wang, S., Sun, Y., Kong, F., Yang, G. and Fatehi, P. (2016) Preparation and Characterization of Lignin-Acrylamide Copolymer as a Paper Strength Additive. BioResources, 11, 1765-1783. https://doi.org/10.15376/biores.11.1.1765-1783

[126] Abdollahi, M., Pourmahdi, M. and Nasiri, A.R. (2018) Synthesis and Characterization of Lignosulfonate/Acrylamide Graft Copolymers and Their Application in Environmentally Friendly Water-Based Drilling Fluid. Journal of Petroleum Science and Engineering, 171, 484-494. https://doi.org/10.1016/j.petrol.2018.07.065 
[127] Fornes, T.D. and Paul, D.R. (2003) Modeling Properties of Nylon 6/Clay Nanocomposites Using Composite Theories. Polymer (Guildf), 44, 4993-5013. https://doi.org/10.1016/S0032-3861(03)00471-3

[128] Liu, H. and Chung, H. (2016) Self-Healing Properties of Lignin-Containing Nanocomposite: Synthesis of Lignin-Graft-Poly(5-acetylaminopentyl acrylate) via RAFT and Click Chemistry. Macromolecules, 49, 7246-7256. https://doi.org/10.1021/acs.macromol.6b01028

[129] Liu, Z., Xu, D., Xu, L., Kong, F., Wang, S. and Yang, G. (2018) Preparation and Characterization of Softwood Kraft Lignin Copolymers as a Paper Strength Additive. Polymers (Basel), 10, Article 743. https://doi.org/10.3390/polym10070743

[130] Liu, H. and Chung, H. (2017) Lignin-Based Polymers via Graft Copolymerization. Journal of Polymer Science Part A: Polymer Chemistry, 55, 3515-3528.

https://doi.org/10.1002/pola.28744

[131] Zhang, N., Wang, S., Gibril, M.E. and Kong, F. (2020) The Copolymer of Polyvinyl Acetate Containing Lignin-Vinyl Acetate Monomer: Synthesis and Characterization. European Polymer Journal, 123, Article ID: 109411.

https://doi.org/10.1016/j.eurpolymj.2019.109411

[132] Don, T.-M., King, C.-F. and Chiu, W.-Y. (2002) Preparation of Chitosan-GraftPoly(vinyl acetate) Copolymers and Their Adsorption of Copper Ion. Polymer Journal, 34, 418-425. https://doi.org/10.1295/polymj.34.418

[133] Qua, E.H., Hornsby, P.R., Sharma, H.S.S., Lyons, G. and McCall, R.D. (2009) Preparation and Characterization of Poly(vinyl alcohol) Nanocomposites Made from Cellulose Nanofibers. Journal of Applied Polymer Science, 113, 2238-2247. https://doi.org/10.1002/app.30116

[134] Nishiyama, Y., Sugiyama, J., Chanzy, H. and Langan, P. (2003) Crystal Structure and Hydrogen Bonding System in Cellulose $\mathrm{I}_{\alpha}$ from Synchrotron X-Ray and Neutron Fiber Diffraction. Journal of the American Chemical Society, 125, 14300-14306. https://doi.org/10.1021/ja037055w

[135] Jiménez Saelices, C., Save, M. and Capron, I. (2019) Synthesis of Latex Stabilized by Unmodified Cellulose Nanocrystals: The Effect of Monomers on Particle Size. Polymer Chemistry, 10, 727-737. https://doi.org/10.1039/C8PY01575A

[136] Zhao, R., Torley, P. and Halley, P.J. (2008) Emerging Biodegradable Materials: Starch- and Protein-Based Bio-Nanocomposites. Journal of Materials Science, 43, 3058-3071. https://doi.org/10.1007/s10853-007-2434-8

[137] Zeng Q.H., Yu A.B., Lu, G.Q.(M.) and Paul, D.R. (2005) Clay-Based Polymer Nanocomposites: Research and Commercial Development. Journal of Nanoscience and Nanotechnology, 5, 1574-1592. https://doi.org/10.1166/jnn.2005.411

[138] Dennis, H.R., Hunter, D.L., Chang, D., Kim, S., White, J.L., Cho, J.W. and Paul, D.R. (2001) Effect of Melt Processing Conditions on the Extent of Exfoliation in Organoclay-Based Nanocomposites. Polymer (Guildf), 42, 9513-9522. https://doi.org/10.1016/S0032-3861(01)00473-6

[139] Salvini, A., Saija, L.M., Finocchiaro, S., Gianni, G., Giannelli, C. and Tondi, G. (2009) A New Methodology in the Study of PVAc-Based Adhesive Formulations. Journal of Applied Polymer Science, 114, 3841-3854. https://doi.org/10.1002/app.31032

[140] Zhang, Y.-R., Wang, X.-L., Zhao, G.-M. and Wang, Y.-Z. (2013) Influence of Oxidized Starch on the Properties of Thermoplastic Starch. Carbohydrate Polymers, 96, 358-364. https://doi.org/10.1016/j.carbpol.2013.03.093 
[141] Takizawa, F.F., de Oliveira da Silva, G., Konkel, F.E. and Demiate, I.M. (2004) Characterization of Tropical Starches Modified with Potassium Permanganate and Lactic Acid. Brazilian Archives of Biology and Technology, 47, 921-931. https://doi.org/10.1590/S1516-89132004000600012

[142] Brown, N.R., Loferski, J.R. and Frazier, C.E. (2007) Cross-Linking Poly(vinyl acetate-co-N-methylolacrylamide) Latex Adhesive Performance Part II: Fracture Mechanics and Microscopic Durability Studies. International Journal of Adhesion and Adhesives, 27, 554-561. https://doi.org/10.1016/j.ijadhadh.2006.10.003

[143] Sangseethong, K., Termvejsayanon, N. and Sriroth, K. (2010) Characterization of Physicochemical Properties of Hypochlorite- and Peroxide-Oxidized Cassava Starches. Carbohydrate Polymers, 82, 446-453. https://doi.org/10.1016/j.carbpol.2010.05.003

[144] Mohsen-Nia, M. and Mohammad Doulabi, F.S. (2011) Synthesis and Characterization of Polyvinyl Acetate/Montmorillonite Nanocomposite by in Situ Emulsion Polymerization Technique. Polymer Bulletin, 66, 1255-1265.

https://doi.org/10.1007/s00289-010-0399-2

[145] Salvini, A., Saija, L.M., Lugli, M., Cipriani, G. and Giannelli, C. (2010) Synthesis of Modified Poly(vinyl acetate) Adhesives. Journal of Adhesion Science and Technology, 24, 1629-1651. https://doi.org/10.1163/016942410X507731

[146] Zou, H., Wu, S. and Shen, J. (2008) Polymer/Silica Nanocomposites: Preparation, Characterization, Properties, and Applications. Chemical Reviews, 108, 3893-3957. https://doi.org/10.1021/cr068035q

[147] Zecha, H. (n.d.) Heat Resistant Emulsion Polymer Dispersion, Manufacture of Aqueous Dispersion, and Adhesive Formulation. EP2138548.

[148] Brown, N.R. and Frazier, C.E. (2007) Cross-Linking Poly[(vinyl acetate)-co-N-methylolacrylamide] Latex Adhesive Performance Part I: N-Methylolacrylamide (NMA) Distribution. International Journal of Adhesion and Adhesives, 27, 547-553. https://doi.org/10.1016/j.ijadhadh.2006.10.002

[149] Liu, Y., Zang, Y.X., Wang, X.H. and Dong, L.M. (2019) Preparation and Cross-Linking Properties of VAc/DAAM Copolymer Emulsion. Materials Science Forum, 953, 141-146. https://doi.org/10.4028/www.scientific.net/MSF.953.141

[150] Ouzas, A., Niinivaara, E., Cranston, E.D. and Dubé, M.A. (2018) In Situ Semibatch Emulsion Polymerization of 2-Ethyl Hexyl Acrylate/n-Butyl Acrylate/Methyl Methacrylate/Cellulose Nanocrystal Nanocomposites for Adhesive Applications. Macromolecular Reaction Engineering, 12, Article ID: 1700068. https://doi.org/10.1002/mren.201700068

[151] Vikman, M., Vartiainen, J., Tsitko, I. and Korhonen, P. (2015) Biodegradability and Compostability of Nanofibrillar Cellulose-Based Products. Journal of Polymers and the Environment, 23, 206-215. https://doi.org/10.1007/s10924-014-0694-3

[152] Geng, S., Shah, F.U., Liu, P., Antzutkin, O.N. and Oksman, K. (2017) Plasticizing and Crosslinking Effects of Borate Additives on the Structure and Properties of Poly(vinyl acetate). RSC Advances, 7, 7483-7491. https://doi.org/10.1039/C6RA28574K

[153] Chu, Y., Cheng, F., Wang, Z., Liu, C. and Liu, M. (n.d.) N-MethylolacrylamideModified Water-Resistant Polyvinyl Acetate Adhesive for Wood and Its Preparation Method. CN104371605.

[154] Ferdosian, F., Pan, Z., Gao, G. and Zhao, B. (2017) Bio-Based Adhesives and Evaluation for Wood Composites Application. Polymers (BaseI), 9, Article 70.

https://doi.org/10.3390/polym9020070 
[155] Mudge, G. and Hespe, P.R. (1990) Water-Resistant Vinyl Polymer Woodworking Adhesives. EP394774.

[156] Jyothi, A.N. and Carvalho, A.J.F. (2013) Starch-g-Copolymers: Synthesis, Properties and Applications. In: Kalia, S. and Sabaa, M., Eds., Polysaccharide Based Graft Copolymers, Springer Berlin Heidelberg, Berlin, Heidelberg, 59-109. https://doi.org/10.1007/978-3-642-36566-9 3

[157] Lanthong, P., Nuisin, R. and Kiatkamjornwong, S. (2006) Graft Copolymerization, Characterization, and Degradation of Cassava Starch-g-Acrylamide/Itaconic Acid Superabsorbents. Carbohydrate Polymers, 66, 229-245. https://doi.org/10.1016/j.carbpol.2006.03.006

[158] Schroegel, O., Bauers, P. and Pankow, F. (2016) Aqueous Polymer Dispersions for Adhesives. DE102015200498.

[159] Kalapathy, U., Hettiarachchy, N.S., Myers, D. and Hanna, M.A. (1995) Modification of Soy Proteins and Their Adhesive Properties on Woods. Journal of the American Oil Chemists' Society, 72, 507-510. https://doi.org/10.1007/BF02638849

[160] Zecha, H. and Kuenstle, H. (2007) Vinyl Ester Based Polymer Latex Composition and Process of Making the Same. US20070088120.

[161] Luo, Z., Liu, P., Xu, W., Fu, J., Xu, L. and Song, J. (2014) Production of Water-Proof Heat-Resistant Flame-Retardant Veneering Adhesive for Furniture Panel. CN103725228.

[162] Shimizu, H., Iwasaki, K., Yanaida, K. and Oshima, S. (1998) Vinyl Acetate Copolymer-Based Aqueous Adhesives and Their Manufacture. JP10036801.

[163] Qiao, Z., Gu, J., Zuo, Y., Tan, H. and Zhang, Y. (2014) The Effect of Carboxymethyl Cellulose Addition on the Properties of Starch-Based Wood Adhesive. BioResources, 9, 6117-6129. https://doi.org/10.15376/biores.9.4.6117-6129

[164] Lehman, J.T., Rhein, N.C. and Anderson, S.W. (2004) One-Part Woodworking Adhesive Compositions Containing Multistage Polymers. US20040003892.

[165] Gong, Y., Shao, T., Wang, X., Zhang, X., Sun, Z. and Chen, L. (2019) Preparation and Characterisation of Modified VAc-VeoVa10 Latex. Pigment \& Resin Technology, 48, 210-215. https://doi.org/10.1108/PRT-05-2018-0045

[166] González-Matheus, K., Leal, G.P. and Asua, J.M. (2015) Film Formation from Pickering Stabilized Waterborne Polymer Dispersions. Polymer (Guildf), 69, 73-82. https://doi.org/10.1016/j.polymer.2015.05.053

[167] Lehman, J.T., Rhein, N.C. and Anderson, S.W. (2004) One-Part Woodworking Adhesive Composition Containing Multistage Polymers. US20040003893.

[168] Herrmann, F. (1973) Poly(vinyl acetate) Coating and Adhesive Compositions. DE2158604.

[169] Bhattacharyya, S.N. and Maldas, D. (1984) Graft Copolymerization onto Cellulosics. Progress in Polymer Science, 10, 171-270. https://doi.org/10.1016/0079-6700(84)90002-9

[170] Zecha, R. and Weissgerber, H. (2008) Formaldehyde-Free Emulsion Polymer Dispersion Composition Including Polyvinyl Alcohol as Colloidal Stabilizer Providing Improved Heat Resistance. EP2000485.

[171] Xu, W., An, Q., Hao, L., Zhang, D. and Zhang, M. (2013) Synthesis and Characterization of Self-Crosslinking Fluorinated Polyacrylate Soap-Free Latices with Core-Shell Structure. Applied Surface Science, 268, 373-380. https://doi.org/10.1016/j.apsusc.2012.12.104

[172] Agirre, A., Weitzel, H.-P., Hergeth, W.-D. and Asua, J.M. (2015) Process Intensifi- 
cation of VAc-VeoVa10 Latex Production. Chemical Engineering Journal, 266, 34-47. https://doi.org/10.1016/j.cej.2014.12.053

[173] Abad, C., De La Cal, J.C. and Asua, J.M. (1995) Emulsion Copolymerization of Vinyl Esters in Continuous Reactors: Comparison between Loop and Continuous Stirred Tank Reactors. Journal of Applied Polymer Science, 56, 419-424. https://doi.org/10.1002/app.1995.070560402

[174] Tanimoto, N. and Inomata, S. (2001) Aqueous Emulsions with Good Water Resistance and Storage Stability for Adhesives. JP2001106855.

[175] Kushida, M. (n.d.) Method for Manufacturing Water-Based Adhesive with Excellent Water Resistance Property. JP5869165.

[176] Saito, M. and Shibuya, M. (n.d.) Storage-Stable Water-Resistant Vinyl Polymer Emulsions Having Stable Adhesive Strength. JP11092609.

[177] Prabhu, R., Jagtap, R. and Digar, M. (2020) Study on Incorporating Wattle Tannin in Polyvinyl Acetate Emulsion and Its Effect on Properties for Wood Bonding Application. SN Applied Sciences, 2, Article No. 1722. https://doi.org/10.1007/s42452-020-03516-1

[178] Tsai, G.-D., Lin, J.-J. and Fan, L.-S. (n.d.) Water-Resistant Polyvinyl Acetate Aqueous Emulsion Used as Adhesive for Wood Material. US20040082706.

[179] Kushida, M. (n.d.) Water-Based Adhesive with Good Water Resistance. JP2017095552.

[180] Orford, P.D., Ring, S.G., Carroll, V., Miles, M.J. and Morris, V.J. (1987) The Effect of Concentration and Botanical Source on the Gelation and Retrogradation of Starch. Journal of the Science of Food and Agriculture, 39, 169-177. https://doi.org/10.1002/jsfa.2740390210

[181] Zhu, M., Qiao, W., Liu, H. and Sun, Y. (2008) Synthesis of a Novel Polymerizable Surfactant and Its Application in the Emulsion Polymerization of Vinyl Acetate, Butyl Acrylate, Veova 10, and Hexafluorobutyl Methacrylate. Journal of Applied Polymer Science, 107, 624-628. https://doi.org/10.1002/app.27123

[182] Zuber, M., Zia, K.M., Bhatti, I.A., Jamil, T., Fazal-ur-Rehman and Rizwan, A. (2012) Modification of Cellulosic Fabric Using Polyvinyl Alcohol, Part-II: Colorfastness Properties. Carbohydrate Polymers, 87, 2439-2446. https://doi.org/10.1016/j.carbpol.2011.11.014

[183] Lu, S., Duan, M. and Lin, S. (2003) Synthesis of Superabsorbent Starch-GraftPoly(potassium acrylate-co-acrylamide) and Its Properties. Journal of Applied Polymer Science, 88, 1536-1542. https://doi.org/10.1002/app.12025

[184] Oh, J.K., Wu, J., Winnik, M.A., Craun, G.P., Rademacher, J. and Farwaha, R. (2002) Emulsion Copolymerization of Vinyl Acetate and Butyl Acrylate in the Presence of Fluorescent Dyes. Journal of Polymer Science Part A: Polymer Chemistry, 40, 1594-1607. https://doi.org/10.1002/pola.10216

[185] Noro, K. (1970) Emulsion Polymerisation of Vinyl Acetate in Relation to the Chemical Structure of Polyvinyl Alcohol. British Polymer Journal, 2, 128-134. https://doi.org/10.1002/pi.4980020206

[186] Schlappa, S., Brenker, L.J., Bressel, L., Hass, R. and Münzberg, M. (2021) Process Characterization of Polyvinyl Acetate Emulsions Applying Inline Photon Density Wave Spectroscopy at High Solid Contents. Polymers (BaseI), 13, Article 669. https://doi.org/10.3390/polym13040669

[187] Asai, M., Yano, D., Mitsuda, M., Kaede, T., Ishii, K. and Matsumoto, N. (n.d.) Plasticizer-Free Adhesive Emulsion Compositions with Low Film-Forming Temperature. JP2003176468. 
[188] Bugada, D.C. and Rudin, A. (1984) Characterization of Poly(vinyl alcohol-acetate) by ${ }^{13} \mathrm{C}$ n.m.r. and Thermal Analyses. Polymer (Guildf), 25, 1759-1766.

https://doi.org/10.1016/0032-3861(84)90248-9

[189] Atanase, L. and Riess, G. (2011) Thermal Cloud Point Fractionation of Poly(vinyl alcohol-co-vinyl acetate): Partition of Nanogels in the Fractions. Polymers (Basel), 3, 1065-1075. https://doi.org/10.3390/polym3031065

[190] Atanase, L.I. and Riess, G. (2010) Poly(Vinyl alcohol-co-vinyl acetate) Complex Formation with Anionic Surfactants Particle Size of Nanogels and Their Disaggregation with Sodium Dodecyl Sulfate. Colloids and Surfaces A: Physicochemical and Engineering Aspects, 355, 29-36. https://doi.org/10.1016/j.colsurfa.2009.11.024

[191] Zecha, H. and Weitzel, H.-P. (n.d.) Method for Producing Vinyl Ester Polymers Having Specifically Settable Dispersity and Low Polydispersity. US 9,650,507 B2.

[192] Matsumoto, M. (n.d.) Plasticizer-Free Vinyl Acetate Polymer Adhesive Compositions with Low Residual Monomer Content, and Their Manufacture. JP2006291043.

[193] Liu, J. and Hoffmann, H. (2004) Hydrogels in Aqueous Phases of Polyvinylalcohol (PVA), Surfactants and Clay Minerals. Colloid and Polymer Science, 283, 24-32. https://doi.org/10.1007/s00396-004-1081-8

[194] Sato, M., Matsumoto, K., Nishimura, M. and Yano, A. (2005) Plasticizer-Free Polymer Emulsion Adhesive Compositions with Good Stability at Low Temperature and Their Manufacture. JP2005097416. 


\section{Abbreviations}

CMR: Carcinogenic, Mutagenic, and Reprotoxic chemicals

PVA: Polyvinyl alcohol

PVAc: Polyvinyl acetate

UF: Urea-formaldehyde resins

PF: Phenol-formaldehyde resins

MF: Melamine-formaldehyde resins

MDF: Medium-density fiberboard

PVC: Polyvinyl chloride

$\mathrm{DH}$ : Degree of hydrolysis

MNT: Montmorillonite

CSNs: Colloidal silica nanoparticles

DMA: Dynamic mechanical analysis

CNC: Cellulose nanocrystals

NMA: N-hydroxymethyl acrylamide

AAEM: Acetoacetoxyethyl methacrylate

Veova: Vinyl ester of versatic acid

MAA: Methacrylic acid

AA-PVA: Acetoacetyl polyvinyl alcohol

API: Aqueous polymer isocyanate

BA: Butyl acrylate 